\title{
FIRMS, JOBS AND EMPLOYMENT IN MOLDOVA
}

\author{
Jan Rutkowski*
}

World Bank Policy Research Working Paper 3253, March 2004

The Policy Research Working Paper Series disseminates the findings of work in progress to encourage the exchange of ideas about development issues. An objective of the series is to get the findings out quickly, even if the presentations are less than fully polished. The papers carry the names of the authors and should be cited accordingly. The findings, interpretations, and conclusions expressed in this paper are entirely those of the authors. They do not necessarily represent the view of the World Bank, its Executive Directors, or the countries they represent. Policy Research Working Papers are available online at http://econ.worldbank.org.

* This paper was prepared for the Moldova Poverty Assessment study. The author is grateful to Reema Nayar and Gordon Betcherman for useful comments and suggestions. 


\begin{abstract}
Despite low open unemployment, labor market outcomes are unsatisfactory in Moldova. Employment is low and job opportunities are scarce. This paper examines labor market performance in Moldova by focusing on firm dynamics. It finds that the low level of employment in Moldova is due to the low rate of firm entry and the low rate of job creation in existing firms. Although the rate of job destruction is high, this is typical of transition economies and is a problem only because it is not coupled with a commensurate rate of job creation. Firm exit is limited and thus is not an important factor behind job losses. The only sector of the economy that creates jobs on a net basis is that of de novo private and small firms. However, in Moldova this sector is significantly smaller than in the most successful transition economies. The paper argues that the primary factor behind the small size of the employment generating sector is the high cost of doing business in Moldova. This includes numerous administrative barriers, intrusive and costly inspections and associated corruption. These costs - extremely high even be regional standards - lower the expected returns to business activity and thus discourage firm formation and growth. The paper recommends improvements in the investment climate as a primary policy to increase productive employment and lower unemployment. Priority should be given to fostering job creation by facilitating the formation of new firms and reducing constraints on the expansion of existing firms. The government should avoid measures designed to forestall the destruction of unviable jobs and firm exit, as these are not conducive to long-run productivity and employment growth. Enhancing labor market flexibility is a further priority, as the current stringent provisions of the Labor Code are not complied with and enforced. Given the unsatisfactory business environment, active labor market programs are unlikely to be effective, unless carefully targeted at the most disadvantaged worker groups.
\end{abstract}




\section{INTRODUCTION}

At first glance, unemployment does not seem to be a large problem in Moldova. After all, the unemployment rate is low, lower than in most transition economies in Central and Eastern Europe (CEE). Does this mean that the labor market performs well? Is job creation high, making it easy to find a new job and escape unemployment? Or does low unemployment mean slow enterprise restructuring, and thus limited job destruction and low inflows into unemployment? This paper attempts to answer these questions by examining labor market dynamics in Moldova, and by specifically focusing on job creation and job destruction. The paper has three objectives. The first is to examine more closely a broader spectrum of measures of labor market performance, focusing on job creation and job destruction, and thus to move beyond the unemployment rate. The second goal is to identify the main factors behind observed labor market outcomes. And the final objective is to recommend actions to improve labor market performance.

The paper finds that despite the low unemployment rate, the labor market in Moldova is depressed and labor resources are substantially under-utilized. The main source of the problem is a low job creation rate, rather than a high job destruction rate. A primary factor contributing to low job creation is the high cost of doing business in Moldova. Improving the business environment is thus the key for better labor market performance, employment growth and ultimately poverty reduction.

The labor market in Moldova has not been analyzed much, with one probable reason being the scarcity of data. The most comprehensive existing study is that by Lindauer (1999), however the author was able to use only aggregate data on major labor market trends and patterns. This paper is the first that utilizes firm-level data coming from the Annual Survey of Enterprises (known as ASA), which made it possible to 
analyze labor market flows (rather than traditional stock measures). ${ }^{1}$ The analysis of job flows helps to better understand forces shaping labor market patterns. In particular, it sheds light on the nexus between the labor market and the business environment, as well as the relationship between employment trends and enterprise restructuring. As such, the analysis of job turnover helps to identify possible causes of observed labor market outcomes.

The rest of the paper is organized as follows. The first section shows key labor market outcomes in Moldova; the second section analyzes job destruction and job creation; and the third section attempts to explain the low rate of job creation in Moldova. The final section summarizes major issues and discusses policy implications.

\section{UNDERUTILIZATION OF LABOR RESOURCES}

Unemployment is low in Moldova, but paradoxically, so is employment. Moreover, many of those who are formally employed are underemployed, and have menial or precarious jobs. Altogether, despite low unemployment, labor resources are substantially underutilized, job opportunities are scarce, and the labor market is depressed.

The ILO/LFS unemployment rate is around 7 percent in Moldova, which is less than in most transition economies of CEE, where unemployment often exceeds 15 percent. It is still lower - barely 2 percent - when one uses the unemployment register data. On the face of it, this relatively low unemployment rate suggests favorable labor market conditions. However in fact it masks a depressed labor market. The most general measure of the utilization of labor resources, the employment ratio, at 57\%, is well below the OECD average of $66 \%{ }^{2}$ This means that some 10 percent of the working age population in Moldova who could have been productively employed is without work. This translates into lower output and ultimately higher poverty, as those without work are disproportionately poor (Andrews, 2003).

\footnotetext{
1 The analysis is confined to the formal sector. However the paper by Andrews (2003) demonstrates that there is not much dynamism in the informal sector, either. Accordingly, the relevant message - that job creation is insufficient in Moldova - is robust to the inclusion of formal sector activities. 2 The employment ratio is the ratio of employment to population of working age, defined as age from 15 -to 64.
} 
Interestingly, the problem of non-employment is more severe among men than women. ${ }^{3}$ Only 71 percent of prime-age men are employed, against 75 percent of primeage women. This is a reversed pattern compared with that prevailing in OECD countries, where the employment ratio among the prime age men is much higher than among women (93 percent and 68 percent, respectively). Thus it is the non-employment of men in Moldova which is the particularly acute problem: over 20 percent of prime age men who are able to work are lacking jobs. This is the most telling indicator of the underutilization of labor resources and the labor market slack in Moldova.

However the actual labor market conditions are still worse. Many of existing jobs are non-regular and add little to the national output. Such menial, low-value-added jobs account for over one-quarter of all jobs. ${ }^{4}$ Examples include casual, short-term or parttime jobs; jobs performed within the household; and non-paid family help, etc. These low-productivity jobs generate low earnings and thus often do not bring the individuals and their families out of poverty.

In addition, many regular jobs are associated with low productivity and underemployment, too. This is caused by two factors. First, many firms in Moldova are struggling to survive and are on the brink of collapse. Second, many firms, especially large ones with some form of state ownership, are still overstaffed. For example, 20 percent of joint stock companies (which as a rule are privatized SOEs) report overstaffing, employing redundant workers who by definition contribute little if anything to the firm's output (ProEra Group, 2003).

The phenomenon of "struggling" or non-viable firms is significant, too. As much as 13 percent of all Moldovan firms, which employ 7 percent of workers, were inactive during at least one month during 2001. One of every 10 workers was on forced unpaid leave in 2001 and the average duration of such leave was three months. As a result of this low and irregular level of firm economic activity, actual hours of work are very low.

\footnotetext{
3 Similar pattern of higher employment rates among men than women was observed in Bulgaria (Rutkowski, 2003b).

According to the LFS 2002, the incidence of non-regular jobs among persons aged 15-64 is 27 percent. Individuals having non-regular jobs are identified as those who (a) reported no paid-job, and (b) reported performing some work as self-employed, on household plot or farm, or (c) had an casual or occasional job in the reporting week, including unpaid job such as helping a family member in the household, store, or enterprise.
} 
An average worker in Moldova works only 28 hours per week, while, say, his Polish counterpart works 42 hours. This is a substantial difference (50 percent), which means that the actual labor input in Moldova is much lower than that implied by already low employment levels.

To conclude, despite relatively low unemployment, the level of utilization of labor resources is very low in Moldova. Many workers have become discouraged by the lack of job opportunities and have withdrawn from the labor force. Moreover, a considerable proportion of those who are employed hold low-value-added jobs, which neither contribute much to the social output, nor generate much earnings. These are casual and menial jobs that bring forth only subsistence income. These also are lowproductivity jobs in non-viable firms, which are barely if at all able to pay wages and salaries. Scarce job opportunities and low productivity of many existing jobs translate into low incomes. Accordingly, the depressed job market is an important factor contributing to high poverty in Moldova. Improving the functioning of the job market and increasing employment is thus key for poverty reduction. The next section looks more closely at the issue of job creation and job destruction, and the factors contributing to employment growth.

\section{Job CREATION AND Job DESTRUCTION}

\section{II.1 Analytical framework}

The employment ratio is a product of two factors: firm density and average firm

size. ${ }^{5}$ Thus, given the population size, the growth in employment requires an increase in the number of firms or in the average firm size, or both. The number of firms increases if the number of firm births exceeds the number of firm deaths. The change in the average firm size, in turn, depends inter alia on the fraction of expanding and contracting firms, and on the job creation and job destruction rates.

5 Firm density is the number of firms relative to the working age population. 
The relationship between employment growth and firm behavior is succinctly captured by the following formula: ${ }^{6}$

$$
l=f^{c}-f^{d}+s^{n} \cdot r^{n}-s^{x} \cdot r^{x}+s^{e} \cdot r^{e} \cdot J C^{e}-s^{c} \cdot r^{c} \cdot J D^{c}
$$

Where: $l$ is the rate of employment growth, $f^{\mathcal{C}}$ is the rate of firm creation, $f^{\mathrm{d}}$ is the rate of firm destruction, $s$ stands for a share, $r$ is the relative firm size, $J C$ is the rate of job creation, and $J D$ is the rate of job destruction. Superscripts have the following meanings: $n$ denotes entering firms, $x$ denotes exiting firms, $e$ denotes expanding firms and $c$ contracting firms.

The above formula is merely an identity, but it stresses the simple yet important fact that employment is determined by firm dynamics and structure. It increases in an environment in which it is easy to open a firm and firms find it profitable to expand. It decreases in an environment where firms find it difficult to survive and there is little room for expansion. The formula also makes it explicit that employment growth reflects dynamic factors (firm entry, expansion, etc.) as well as structural factors (proportion of expanding firms, firm size, etc.).

A more in depth explanation of labor market outcomes requires of course to identify determinants of firm births and deaths, as well as determinants of job creation and job destruction. In most general terms, firm entry and job creation depend on the expected rate of return to creating a job. All factors that raise the expected costs or decrease the expected benefits discourage firm entry and job creation. There has been a lot of theoretical and empirical research attempting to identify such factors, and the knowledge what is good and what is bad for job creation is quite advanced. ${ }^{7}$ The advantage of the above formula for job creation is that it can guide the search for explanations, points to areas that should be examined. For example, the low rates of firm entry and job creation suggest different set of explanations than the high rates of firm exit and job destruction. By similar vein, information that firms which create jobs are small, but the fraction of such firms is low provides a valuable hint that structural factors (e.g. barriers to entry, slow privatization) may be at play.

\footnotetext{
$6 \quad$ See Annex 1 for the derivation of the formula. The formula has an approximate character and is valid for "small" changes in the number of firms and the average firm size.

7 The literature on this subject is enormous. Most recent positions include (Nickel, 1997; Garibaldi and Mauro, 1999; Blanchard and Wolfers, 2000; Boeri et al., 2000; Heckman and Pages, 2000; Haltiwanger et al., 2003.
} 
In the rest of the section we analyze the components of the employment growth formula in turn, gathering clues as to factors contributing to the poor job creation record of the Moldovan economy.

\section{II.2 Firm entry and exit ${ }^{8}$}

A growing body of literature on labor market performance emphasizes the role of entrepreneurship and firm dynamics. In an environment which is conducive for entrepreneurship and where starting-up a business is easy labor market outcomes, such as the employment ratio, tend to be significantly better than in an environment where there are restrictions on entrepreneurs an it is difficult to open a firm (Krueger an Pischke, 1997; Boeri and Martins, 2000; Scarpetta et al., 2002; Lopez-Garcia, 2003).

The rate of firm creation has been and still is low in Moldova, especially by the standards of other transition economies. In addition, the already modest rates of firm creation observed in mid- to late 1990s, plummeted in 1999 and since then stabilized at a low level (Table 1). Presently, the rate of firm creation is 7-8 percent for firms which are legal persons, and around 5 percent for firms which are natural persons. ${ }^{9}$ These figures should be contrasted with the average enterprise creation rate of 16-18 percent prevailing in transition economies of Central Europe (Eurostat, 2000). In Romania - Moldova's neighbor - the firm creation rate in the late 1990s exceeded 20 percent. So, it was three times as high as in Moldova. This is a striking difference. Against this background Moldova's record of firm creation is bleak indeed.

Particularly indicative is the low rate of creation of firms which are natural persons. In most transition economies the number of such firms has mushroomed, and they account for the majority of all firms. Enterprises that are natural persons have a sole proprietor and are small. ${ }^{10}$ As such, this is a legal form well suited to the needs of small

\footnotetext{
8 The empirical analysis in this Section is based on the results of the Annual Survey of Enterprises, which covers firms registered with the official RENIM register. The survey is carried out by the Moldovan Department of Sociology and Statistics (DSS). A detailed description of the survey is provided in Annex 2.

$9 \quad$ This rates are underestimated insofar the overall number of firms is overstated due to the artificially low rate of firm closures. This does not alter the qualitative nature of the conclusion that the rate of firm creation is low in Moldova.

10 Firms that are natural persons include the self-employed (in this case they have no salaried employees)
} 
entrepreneurs and the emerging market economy. To be sure, the number of such businesses has grown in Moldova, by almost 25 percent over the five year period 19972002. But this is much less than in other countries, where the growth rates are much higher. The most likely reason behind this relatively slow pace of firm creation is high costs associated with opening and running a business. In the case of small entrepreneurs these costs may be prohibitive, discouraging them from opening a business. The high costs of doing business in Moldova as a likely cause of unsatisfactory job creation record is a recurrent theme of this paper. Direct evidence in favor of this hypothesis will be presented in Section III.

Table 1 Firm openings and closures, 1997-2002

\begin{tabular}{|c|c|c|c|c|c|c|}
\hline Firm category & 1997 & 1998 & 1999 & 2000 & 2001 & 2002 \\
\hline \multicolumn{7}{|l|}{ Firm openings } \\
\hline Natural persons & 14.3 & 11.2 & 4.1 & 3.4 & 3.6 & 4.8 \\
\hline Legal persons & 10.3 & 9.3 & 8.1 & 8.1 & 7.8 & 7.4 \\
\hline \multicolumn{7}{|l|}{ Firm closures } \\
\hline Natural persons & 1.6 & 1.6 & 0.8 & 2.4 & 2.8 & 2.5 \\
\hline Legal persons & 1.6 & 1.1 & 0.8 & 2.4 & 0.7 & 0.5 \\
\hline \multicolumn{7}{|l|}{ Firm turnover } \\
\hline Natural persons & 15.9 & 12.8 & 4.9 & 5.8 & 6.4 & 7.3 \\
\hline Legal persons & 11.9 & 10.3 & 8.9 & 10.5 & 8.4 & 7.9 \\
\hline
\end{tabular}

Note: Data refer to registered firms covered by the RENIM register.

Source: Department of Statistics and Sociology; author's calculations.

The low rate of firm creation directly translates into a low rate of job creation. Evidence from other transition economies shows that firm openings create from onefourth to one-third of all new jobs (Rutkowski 2001, 2003a). Employment costs of slow firm entry are thus substantial. The insufficient rate of firm creation is an important factor contributing to low employment level in Moldova.

The rate of firm closure is negligible in Moldova, although it has increased since 2000. Still, only less than 3 percent of all firms are closed yearly. This is an especially low figure given that there is a substantial fraction of inactive or semi-active (active only for a part of a year) firms in Moldova. This discrepancy between firm closures and inactivity is probably caused by the fact that formal closure or bankruptcy procedures are complicated and costly. Therefore many non-viable firms seem to prefer to suspend their activity rather than close. From the viewpoint of worker and social welfare, however, the 
result is similar. Moribund firms often do not pay wages, send workers on unpaid leave and thus provide fictitious employment.

Moreover, an artificially low rate of firm closures has a negative impact on economic efficiency. Resources, including labor are frozen in non-viable firms, which inhibits restructuring and productivity growth. To improve economic efficiency these resources need to be moved toward more productive uses, which requires the closure of inefficient firms. The exit of inefficient firms is thus a necessary, although not a sufficient, condition for the entry of new firms (World Bank, 2002).

To conclude, firm turnover in Moldova is low by standards of transition economies. Few inefficient firms are closed, and - probably not independently - few new firms are being created. The slow pace of new firm formation in Moldova accounts for the relatively small size of the "new" dynamic sector of the economy (see below). It also limits job creation, for experience from other countries shows that opening firms create a substantial fraction of all new jobs. Fostering the entry of new firms is thus key for faster job creation and employment growth.

\section{II.3 Expanding and contracting firms}

Most firms in Moldova reduce employment and the majority of workers are in the downsizing firms (Figure 1). ${ }^{11}$ The ratio of contracting firms to expanding firms is 4 to 3 . However, given that the contracting firms tend to be larger than the average, roughly twice as many workers are in the contracting firms than in the expanding firms (61 percent against 32 percent, respectively).

11 The analysis is limited to the formal sector. Although the size of the informal sector is substantial in Moldova, it is not a source of gainful job opportunities, see Andrews (2003). 
Figure 1 Firms and Employment by firm growth status, 2001
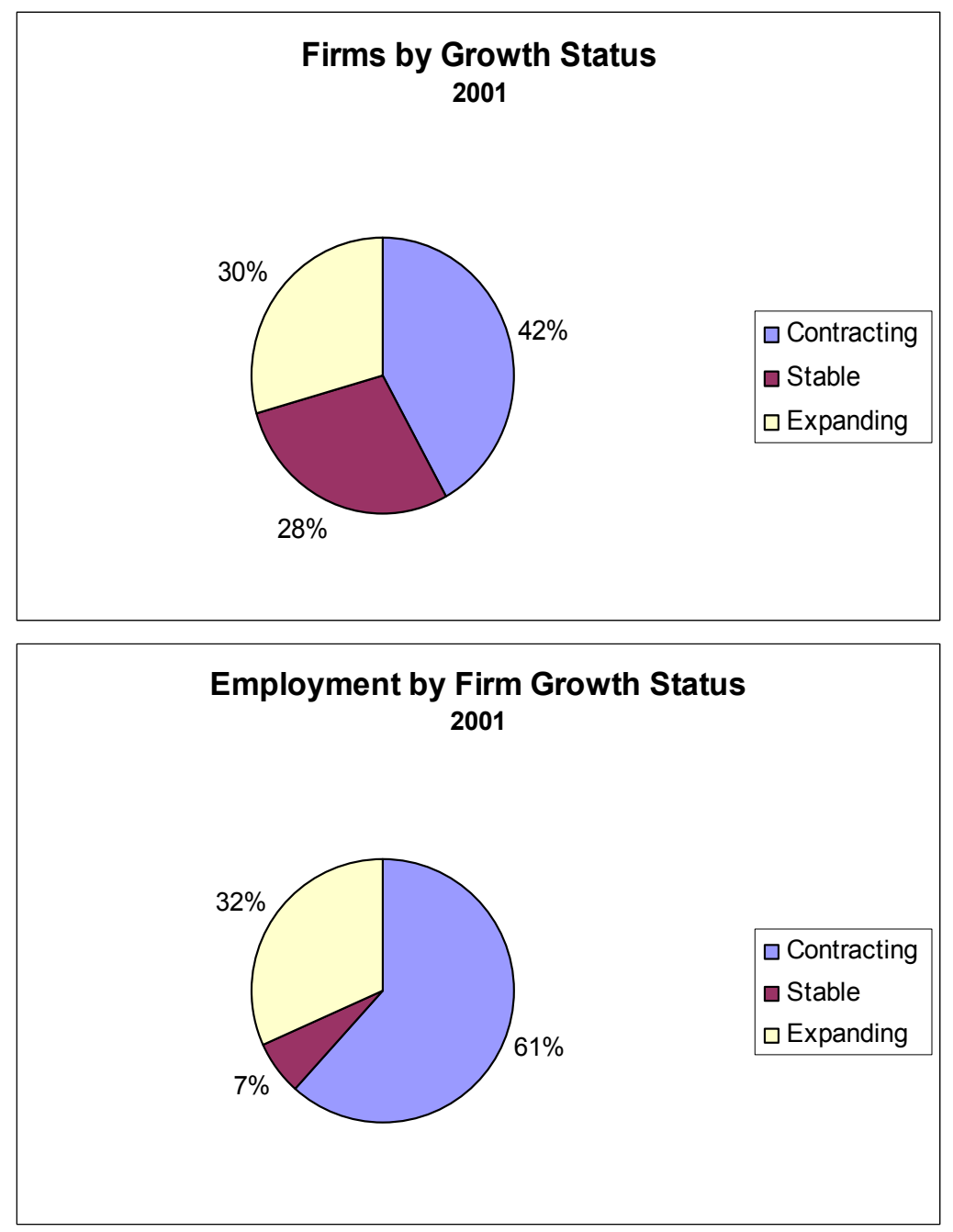

Source: Annual Survey of Enterprises, 2001; author's calculations.

The expanding firms increase employment somewhat less than the declining firms decrease it. An average employment reduction is 16 workers, while an average employment expansion is 13 persons (Table 2). This is not a huge difference, however given the preponderance of shrinking firms, it translates into total job loses far outnumbering total job gains. 
Table 2 Expanding and contracting firms, 2001

\begin{tabular}{lrrrrrr}
\hline Firm category & $\begin{array}{c}\text { Share in } \\
\text { firms (\%) }\end{array}$ & $\begin{array}{c}\text { Share in } \\
\text { employment } \\
(\%)\end{array}$ & $\begin{array}{c}\text { Average firm } \\
\text { size (persons) }\end{array}$ & \multicolumn{2}{c}{$\begin{array}{c}\text { Change in employment } \\
\text { (persons) }\end{array}$} \\
\hline All firms & & & & Median & Mean & $\begin{array}{r}\text { Standard } \\
\text { Deviation }\end{array}$ \\
Contracting & 100.0 & 100.0 & 57.7 & 0 & -2.9 & 28.2 \\
Stable & 42.0 & 61.7 & 84.7 & -5 & -16.1 & 30.6 \\
Expanding & 28.5 & 6.6 & 13.4 & 0 & 0.0 & 0.0 \\
\hline
\end{tabular}

Source: Annual Survey of Enterprises, 2000 and 2001; author's calculations.

This pattern of widespread enterprise downsizing is quite typical of transition economies and Moldova is not an exception. The reason behind labor shedding during the economic transition is a drive toward greater economic efficiency. Firms shed redundant labor to eliminate the inherited overstaffing, to close low value-added jobs, and ultimately to improve productivity. For example, the proportion of firms in Moldova which reported overstaffing fell from 19 to just 6 percent from 2001 to 2002, which is a clear sign of better firm governance and performance (ProEra Group, 2003). As such, enterprise downsizing is a desirable process, resulting in firms being more efficient and competitive.

What is worrisome, is that this process of elimination of non-viable jobs is not accompanied by commensurate job creation. In contrast, successful transition economies managed to achieve "creative destruction", whereby destruction of old, unproductive jobs is matched by the creation of new, more productive jobs. For example, while the proportion of shrinking firms in Moldova is virtually the same as in Lithuania, the proportion of expanding firms is significantly smaller (30 percent against 37 percent). Accordingly, the job creation rate in Lithuania is higher than in Moldova.

To conclude, Moldova is undergoing a widespread process of the elimination of unproductive jobs, which to a varying degree is characteristic of all transition economies, and by itself is not a negative phenomenon. Actually, insofar as it leads to firms being more productive and more competitive, it is a positive development. However, the problem is that the old jobs are not being sufficiently fast replaced by new, more productive jobs. This causes the total pool of jobs to diminish, meaning deteriorating 
employment prospects. To overcome this negative trend the proportion between expanding and declining firms needs to change in favor of the former. This requires faster entry of new, dynamic firm and the faster growth of the "new" sector of the economy. A prerequisite for achieving these objectives is the business friendly environment, and issue that is addressed in Section III.

\section{II.4 Job creation and job destruction}

\section{Moldova against other countries}

The job creation rate and the job destruction rates are key concepts underlying the analysis of labor market dynamics. Jointly, these two rates determine the rate of employment growth and job turnover (see Box 1 for the description of the relevant measures). 


\section{Box 1 \\ Job Turnover and its Components}

The gross job creation rate (JC) is defined as the sum of all employment gains in expanding firms in a given year, expressed as a proportion of total employment at the beginning of the year.

The gross job destruction rate (JD) is defined as a sum of all employment losses in contracting firms in a given year, expressed as a proportion of total employment at the beginning of the year.

The job turnover rate (JT) is defined as the sum of the absolute value of the change in employment in each firm, expressed as proportion of total employment. Put differently, job turnover is the sum of the job creation and job destruction rates (i.e. JT $=\mathrm{JC}+\mathrm{JD}$ ).

The difference between JC and JD gives the rate of employment growth (EG), or the net job creation rate (i.e. $\mathrm{EG}=\mathrm{JC}-\mathrm{JD}$ ).

The job reallocation rate (JR), also called "excess" job reallocation, is the job turnover rate beyond that necessary to accommodate the net change in employment. Thus JR is the difference between JT and the absolute value of EG. Alternatively, JR equals to twice the JC or JD, whichever is smaller (i.e. JR $=2 * \min \{\mathrm{JC}, \mathrm{JD})$.

The job reallocation rate is often used as an indicator of enterprise restructuring. Restructuring is assumed to be the more intensive, the more jobs are moved away from contracting firms toward expanding firms. For example, a job reallocation rate of $20 \%$ means that $10 \%(20 / 2)$ of all jobs were shifted from contracting firms to expanding firms. Notice that that the degree of job reallocation is determined by the lower of the rates of job creation and job destruction.

The concept of job turnover is often confused with that of labor turnover. The rate of labor turnover is the sum of hires and separations. However, not every hiring means that a job was created, and not every separation means that a job was destroyed. A new job was created only if a hiring was not preceded by a separation. And a job was destroyed only if a separation was not followed by hiring. Thus, labor turnover encompasses job turnover. The concept of labor turnover refers to the movements of persons, that of job turnover is limited to movements of jobs.

Why is the analysis of job creation and job destruction important? First, it provides important characteristics of labor market performance and structure. The difference between the job creation rate and the job destruction rate gives the rate of employment growth. This rate indicates if employment opportunities are improving or deteriorating, and directly influences the level of unemployment. The sum of job creation and job destruction rates produces the job turnover rate. Higher job turnover 
improves the chances to escape unemployment and is associated with the shorter duration of job search. Thus, these two measures taken together point either to a growing and dynamic labor market, or to one that is shrinking and stagnant.

Second, job turnover shows the extent of reallocation of jobs across firms and is thus indicative of the intensity of enterprise restructuring. High job reallocation points to the labor market supporting industrial restructuring and productivity improvements. Low job reallocation, in turn, may point to constraints to restructuring, such as high firing and hiring costs, or low expected returns to firm creation. The degree of job reallocation has a bearing on overall economic efficiency and growth, which require shifting jobs away from declining, low-productivity firms and industries toward expanding ones.

How does job turnover in Moldova compare to that in other countries? The pattern of job creation and job destruction in continuing firms in Moldova is similar to that in other low-employment transition economies, such as Bulgaria (Figure 2). ${ }^{12}$ Its characteristic feature is a substantial gap between job creation and job destruction, which implies a fall in the employment level. ${ }^{13}$ This pattern can be assessed against three different benchmarks: (i) a non-restructuring, stagnant economy (e.g. Croatia), (ii) a mature market economy (France), and (iii) a restructuring, dynamic economy (e.g. Lithuania). Lithuania is the most adequate point of reference: enterprise restructuring proceeds at a high pace, the labor market is dynamic, and most importantly, destruction of non-productive, old jobs in is followed by commensurate creation of new, presumably more productive jobs. High job turnover, such as that prevailing in Lithuania, may create problems of its own (spatial and skill mismatches and associated frictional and structural unemployment). However the underlying dynamic labor market is conducive to improvements in productivity and competitiveness, as well as to shorter and more

12 Continuing firms are firms which were active in two consecutive periods under investigation.

13 The fall in employment during the period 2000-2001 implied by the analysis of job creation and job destruction is greater than that shown in official publications (DSS, 2002). This discrepancy reflects differences in sources of data and consequently definitions of employment, and the coverage of firms and workers. Data presented here are derived from an employer based survey which covers firms registered as legal persons. In contrast, the DSS reports employment data coming from the household based Labor Force Survey, which covers both formal and informal sector workers, including the self-employed, regardless of the nature of their job and their firm's legal status. 
successful jobs search. If job creation is high, then it takes less time and it is easier to find a new job.

Figure 2 Job creation and job destruction: Moldova against selected countries

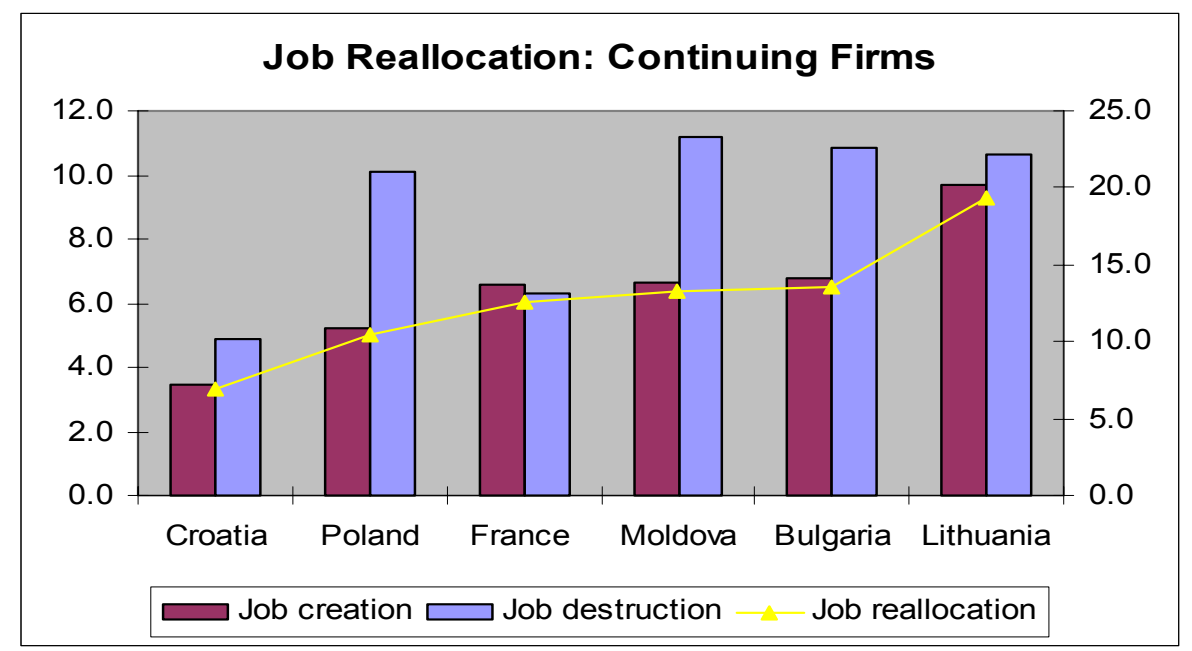

Source: Annual Survey of Enterprises, 2000 and 2001; author's calculations.

Against this benchmark, the Moldavian labor market does not perform very well. Enterprise restructuring and associated reallocation of resources from less toward more productive uses is limited due to the low job creation rate. The job creation rate in continuing enterprises in Moldova is only about two-thirds of that in Lithuania (Table 3). At the same time, the job destruction rate in Moldova is somewhat higher than in Lithuania. If few new jobs are being created there is not much scope for the reallocation of old jobs. Thus the low job creation puts a ceiling on job reallocation. As a result, the job reallocation rate is lower and enterprise restructuring is slower in Moldova than in Lithuania. To the extent job reallocation brings about productivity gains, slower pace of enterprise restructuring in Moldova translates into lower than otherwise productivity growth, and accordingly, lower income growth. 
Table 3 Job creation and job destruction: Moldova against selected countries

\begin{tabular}{lrrrrrr}
\hline & Moldova a) & Croatia a) & Bulgaria a) & Lithuania a) & Poland a) & France \\
\hline & 2001 & 2001 & 2000 & $1998-99$ & 1999 & $1984-91$ \\
Job creation & 6.7 & 3.5 & 6.8 & 9.7 & 5.3 & 6.6 \\
Job destruction & 11.2 & 4.9 & 10.8 & 10.7 & 10.1 & 6.3 \\
Employment growth & -4.5 & -1.4 & -4.1 & -0.9 & -4.8 & 0.3 \\
Job turnover & 17.8 & 8.4 & 17.6 & 20.4 & 15.4 & 12.9 \\
Job reallocation & 13.3 & 7.0 & 13.5 & 19.4 & 10.5 & 12.6 \\
\hline
\end{tabular}

a) Registered legal persons.

Note: Continuing firms (i.e. firm openings and closures are excluded).

Sources:

Moldova: Department of Statistics and Sociology; author's calculations.

Croatia: Central Bureau of Statistics; author's calculations.

Bulgaria: Rutkowski (2002b)

Lithuania: Rutkowski (2002a)

Poland: Rutkowski (2001)

OECD countries: OECD (1996)

Furthermore, employment prospects faced by the unemployed in Moldova are poor as the overall pool of jobs is shrinking. As fewer jobs are being created than destroyed, the job losers find it difficult, if not impossible, to find a new job. Again, the comparison with Lithuania is instructive. While the job destruction rate in Moldova is similar to that in Lithuania, the job creation rate is significantly lower. So, the problem faced by Moldova is not as much high job destruction as insufficient job creation. As a result of this gap between job creation and job destruction, Moldovan jobseekers face worse chances of finding a job than their Lithuanian counterparts.

The focus on continuing firms (dictated by data availability) is likely to produce too rosy a picture of the labor market in Moldova. If one allows for the fact that firm openings (as well as closures) are probably less prevalent in Moldova than in other transition economies, then labor market in Moldova turns out to be even less dynamic. In particular, it lacks the significant dynamism springing form the birth of new firms and job opportunities that they create.

What does the pattern of high job destruction coupled with modest job creation tell us about labor market conditions in Moldova? High job destruction suggests that dismissal costs are not so high as to forestall the destruction of non-viable, low productivity jobs. This is in contrast to, for example Croatia, where extremely high costs 
of dismissal are an obvious cause of low job destruction, and consequently, low job creation (Rutkowski, 2003). This is apparently not the case in Moldova.

This is an important finding since to some extent it contradicts the perception that dismissals are difficult and costly in Moldova due to strict provisions of the Labor Code. For example, the Labor Code provides for trade union approval for dismissals, which is a rare provision in market economies and may make dismissals difficult. It also seems to contravene employers' claims that high procedural and monetary costs of dismissals prevent them from eliminating overstaffing (ProEra, 2002) ${ }^{14}$ However, these seemingly contradictory pieces of evidence can be reconciled. First, the high rate of job destruction suggests that the Labor Code is not enforced in a considerable segment of the formal sector. Second, the Labor Code provisions regarding dismissals are likely to be binding in larger firms with union presence and history of state ownership. These are exactly the firms which most often report overstaffing. Third, as long as dismissal costs are not prohibitive, it may pay employers to incur them in order to reduce future labor costs and improve firm competitiveness. The conclusion seem to be that for some firms dismissal costs can be substantial and slow down employment restructuring, however all in all they do not prevent the elimination of unproductive jobs. In short, dismissal costs are probably a problem in Moldova, but not an insurmountable problem.

Slow job creation should not thus be attributed to excessive hiring and firing costs. In this context, the most likely cause is the poor business environment and high costs of doing business. Firms do not create jobs if the costs of creating a job outweigh the net present value of benefits the job is expected to generate. The poor business environment both increases the costs of creating jobs and reduces the expected benefits. Factors that increase costs of doing business include permits, licenses, certificates, custom procedures, and opportunity costs associated with inspections and audits. In turn, factors that reduce benefits include: arbitrary penalties and fines, bribes and taxes. In Section III we examine these factor in more detail in order to test the hypothesis that

14 Among managers of overstaffed companies 33\% avoided dismissals because they are a lengthy and expensive process, another $9 \%$ were afraid of problems with state authorities, and $2 \%$ wanted to avoid problems with trade unions (ProEra, 2002). Thus, in some cases dismissals may be difficult in Moldova. 
indeed high costs of doing business in Moldova is the primary cause of insufficient job creation.

To conclude, the characteristic feature of the labor market in Moldova is the high rate of job destruction, which is typical of most - although not all - transition economies. This is a healthy process inasmuch as it reflects enterprise restructuring and elimination of low productivity jobs in industries in which Moldova does not have a comparative advantage. However, high job destruction is not matched by an equally high job creation, which results in net job loses. This significant gap between job creation and job destruction - larger than in more dynamic transition economies - is a source of labor market slack and negatively affects workers' chances to find productive employment. The gap also encumbers industrial restructuring, as there is not enough new jobs to accommodate workers displaced from the old jobs. Hence, the room for worker reallocation is limited. The labor market in Moldova lacks necessary dynamism to provide employment to all who seek it. Insufficient job creation is the result of a combination of factors, of which many are beyond the labor market. Experience from other counties indicates that often an important cause of weak labor market performance is the poor business environment, which is likely to be the case also in Moldova. This link is explored in the further part of the paper.

\section{Job turnover by employer characteristics}

What kind of firms tend to create jobs, and what kind of firms tend to destroy jobs? The answer to this question is provided in Table 4. 
Table 4 Job creation and job destruction by sector, 2001

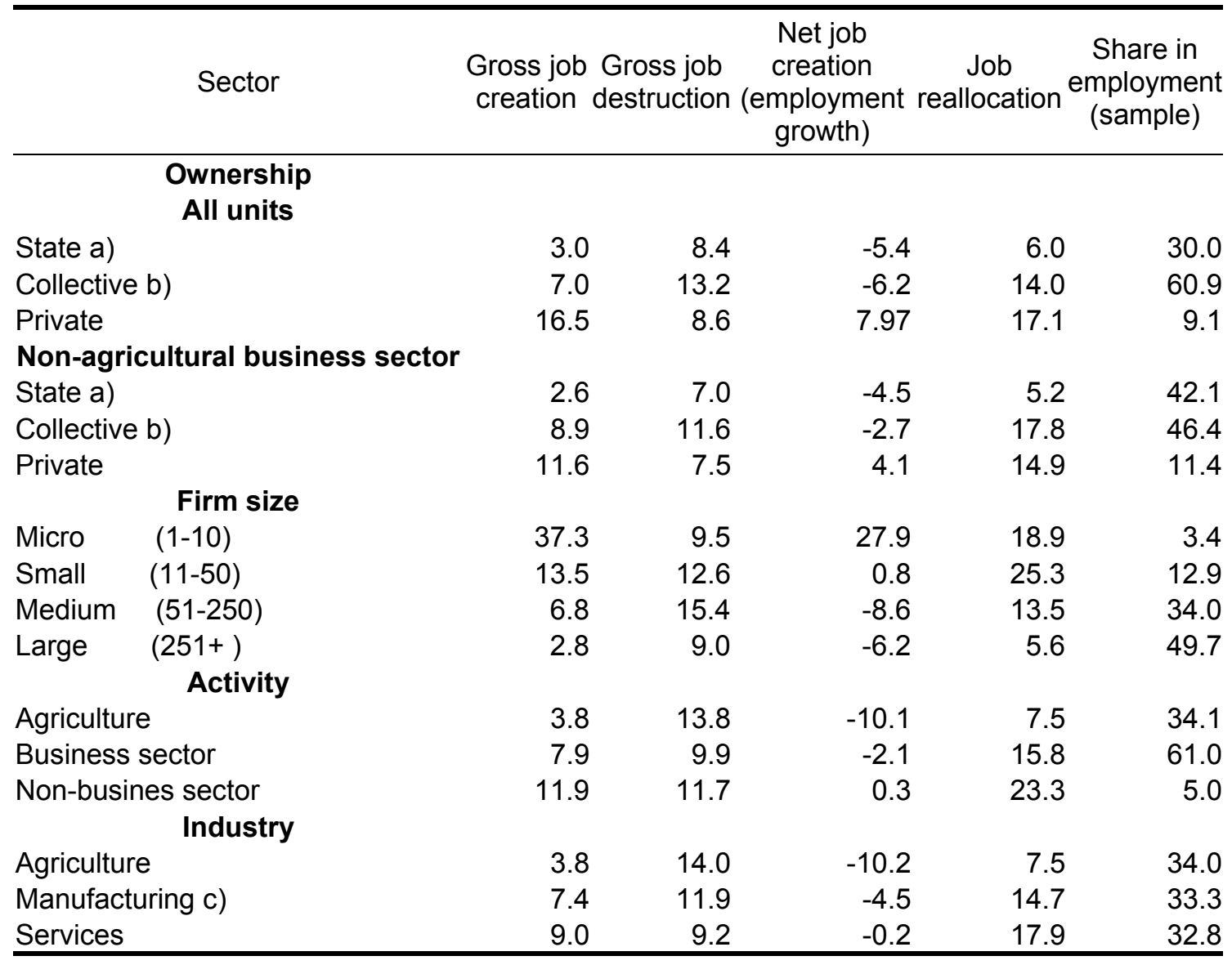

Note: Data refer to continuing firms which are registered legal persons.

State ownership includes municipal and mixed state/private ownership.

b) "Collective" ownership includes joint-stock companies, cooperatives, and social or political organizations. Joint-stock companies are either state-owned or privatized.

c) Including mining and construction.

d) Including mining, electricity, gas and water.

e) Social, community and personal services.

Source: Annual Survey of Enterprises, 2000 and 2001; author's calculations.

\section{Firm ownership}

One of the key firm characteristics is ownership, which influences governance and is reflected it the firm's behavior. Data on job turnover by firm ownership strongly 
support this view. The pattern of job turnover in private firms is very much different from that in public and privatized ("collectively owned") firms. ${ }^{15}$

Let's focus on the non-agricultural business sector. The job creation record of state firms is dismal. They create less than three new jobs per every 100 existing jobs (per year). Privatized firm perform better, with the annual gross job creation rate at close to 9 percent. However, only the genuinely private firms expand at a relatively fast pace: they create almost 12 new jobs per 100 existing jobs. This clearly shows that ownership matters, and the strong job creation potential exists only in the private firms.

This claim is reinforced when one looks at the job destruction rates. Privatized firms perform badly on this count, destroying close to 12 percent of their jobs. Both state owned and private firms destroy around 7 percent of their jobs per year.

As a result of a high job creation rate and a modest job destruction rate, the private sector creates jobs on a net basis, and increases its employment (at some 4 percent per year). In contrast, both the state owned and privatized sectors destroy jobs on a net basis, i.e. decreases their employment (about 3 to 5 percent). Again, this shows that only the private sector is the provider of job opportunities and the source of employment growth.

Interestingly, the job reallocation rate is the highest among the privatized firms. Within this segment of the labor market, about nine percent of all jobs are moved away from the declining firms toward the expanding firms. This points to a high degree of heterogeneity among the privatized firms: some of them behave like the private firms and

15 The classification of ownership used in this paper differs from that used in the official Moldovan statistics. According to official statistical sources, the so called "collective property" is part of the private sector. However the bulk of "collective firms" are formerly state owned enterprises turned into joint stock companies and partly or fully privatized. (In addition, "collective firms" comprise cooperatives, firms owned by organizations, etc.). Analysis shows that these privatized firms behave very much differently from genuinely private firms and therefore lumping them together may be misleading. Accordingly, in order to obtain a clear picture of job turnover by firm ownership, the paper presents data on "collectively owned" firms" separately from those on private firms. Note that as a result of this separation of "collective firms" the share of private sector in employment is substantially smaller than officially reported. 
show potential for growth, while others still resemble the state owned enterprises and reduce employment. ${ }^{16}$

The superior employment performance of private firms compared with public firms is not surprising and is what one would have expected in a transition economy. The problem is however that the size of the job creating private sector is small in Moldova, which severely limits its employment generation potential. In the non-agricultural business sector the share of private firms in employment is only 11 percent. The difference between this figure and the high share of the private sector reported in official statistics is made up by the "collectively owned" (privatized) firms, which are officially categorized as private firms. However, as we have just seen, in terms of job creation they are very different from the genuinely private firms: the privatized firms tend to reduce employment while private firms increase it. Thus, the point is valid that the size of the dynamic "new" private sector is small. The increase in the share of this sector requires a higher pace of the formation of new firms, a point that already has been raised and to which we will return later when discussing barriers to job creation.

\section{Firm size}

Job turnover also varies substantially by firm size. Smaller firms are much more dynamic than larger ones. ${ }^{17}$ The job creation rate sharply decreases with firm size. In contrast, the variation in job destruction rates is much smaller. As a result, only the small firm sector (consisting of firms employing up to 50 workers) is a net creator of jobs and increases its employment. The large firm sector is shrinking. Consequently, the small firm sector accounts for a disproportionately large part of job creation (Figure 3).

\footnotetext{
16 In fact, employment reductions can have different economic meaning. There may be active employment reduction aimed to reduce costs and improve the firm's competitiveness, and reactive reductions reflecting worsening economic conditions faced by the firm.

$17 \quad$ Variation in the job turnover rates by size is not independent of variation by ownership since small firms tend to be privately owned while larger firms are either state owned or privatized.
} 
Figure 3 Job Creation an Employment by Firm Size
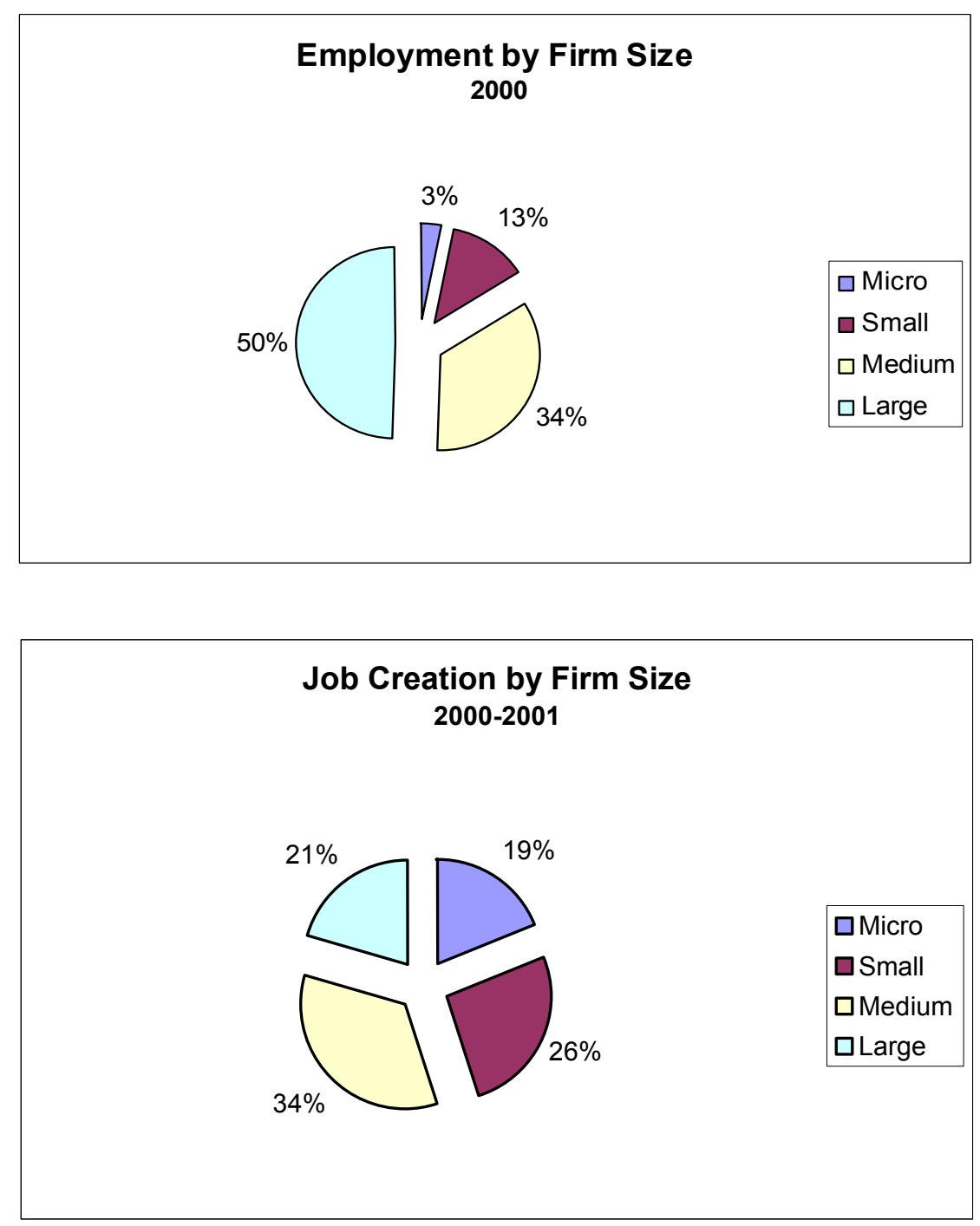

Source: Annual Survey of Enterprises, 2001; author's calculations.

Although the small firm sector as such is expanding, this is associated with substantial job reallocation among small firms. To illustrate, one out of eight jobs is moved from one small firm to another within a year. This high job turnover epitomizes a dynamic labor market and implies that those who are looking for a job have a better chance to find one. At the same time, however such high job turnover contributes to frictional unemployment, as it takes time for workers to move from old to new jobs. 
Small firms constitute the most dynamic segment of that labor market virtually everywhere and Moldova is not an exception in this respect. What matters for job creation is the size of the small firm sector. Here again Moldova is lagging behind, as its small firm sector is small by standards of successfull transition economies. According to the survey of employers (ASA), only 17 percent of workers are employed in small (up to 50 employees) firms. In contrast, in Lithuania almost one-third of all workers are employed in small firms. ${ }^{18}$ Hence, the small enterprise sector is underdeveloped in Moldova. This is another reason for the unsatisfactory job creation record of the Moldavian economy, which again points to the unfriendly business environment.

\section{Business vs. non-business sector firms}

A surprising feature of the Moldavian labor market is that job turnover in the nonbusiness sector is substantially higher than in the business sector. Usually, the nonbusiness sector, consisting of public and social services, is the source of stable jobs. In contrast, the business sector, exposed to fluctuations in product demand, offers less stable jobs and is thus characterized by higher job turnover. This apparently is not the case in Moldova. Job turnover in the non-business sector is very high, with both the job creation and job destruction rates approaching 12 percent. This implies considerable movements of worker from downsizing institutions and organizations toward expanding ones.

In contrast, job turnover in the business sector is at a modest level, with the rate of job creation some 30 percent lower than in the non-business sector and the rate of job destruction $20 \%$ lower. Accordingly, contrary to what one would have expected, fewer workers change jobs in the business than in the non-business sector.

The distinctive feature of the agricultural sector is low job creation (less than four percent), and high job destruction (close to 14 percent), and thus a substantial fall in the overall number of jobs in the formal sector agricultural enterprises. However, this fall

18 These figure are likely to be biased downward as they relate only to firms which are legal persons (firms owned by natural persons are as a rule small). However, the point that is being made is that the size of the small enterprise sector in Moldova is much smaller than in Lithuania and other successful transition economies. 
has not been accompanied by a similar fall in total agricultural employment, implying that many workers who lost their jobs in agricultural firms moved to individual farming. ${ }^{19}$

To sum up, the two most characteristic features of job turnover by sector of activity are (a) relatively low job turnover in the business sector in contrast to high job turnover in the non-business sector, and (b) large-scale reallocation of jobs away from the formal, enterprise-based agriculture to individual, likely informal, farming.

\section{Industry}

Job turnover tends to vary substantially by industry. There are high job creation, high job turnover industries, which provide employment opportunities and improve chance to escape unemployment, even if high job creation accompanied by high job destruction (a typical example is construction industry). On the other extreme, there are low job destruction, low job turnover industries, which offer stable, secure jobs, but at the same time hire few new workers and thus provide little opportunity for the job seekers (a typical example is civil service). Then there are expanding industries, where job creation exceeds job destruction, and which provide good prospects for long-term employment. Finally, there are declining industries, where employment is falling and thus jobs are at risk and hiring is limited.

Industries where the job creation rate is high in Moldova include manufacturing of office machinery and paper, wholesale trade, financial intermediation, real estate and the so-called "other business activities", and somewhat surprisingly, education and health care. $^{2021}$ Most of these high job turnover industries create more jobs than destroy and thus improve employment opportunities. However, with the exception of trade, these industries account for a small share of total employment, which limits their overall impact. Nonetheless, it is important to realize that although the labor market at large is depressed, there are emerging oases of employment growth, activities where Moldova

19 According to the LFS data, total agricultural employment increased considerably in the late 1990s, from 683 thousand workers in 1997 to 764 in 2001 (DSS, 2002).

20 Note: Data refer to the employment change within one year only, and as such are not necessarily representative of a long-term trend.

21 "Other business activities" include legal services, accounting, business counseling, marketing, personnel recruitment, etc. These activates, associated with the development of a market economy, are expanding in virtually all transition economies of CEE. 
may have comparative advantage and which have the potential to lead the restructuring of the economy.

The low-job-turnover industries, where job destruction is low but so is job creation, include water supply, public administration post and communication. These industries provide secure jobs for insiders, however offer little employment chances for outsiders, i.e. those looking for work.

The shrinking industries include the computer industry, manufacture of RTV, communication and other electrical equipment, manufacture of medical and precision instruments, manufacture of chemicals and chemical products, metal processing, as well as construction. Most of these industries are in the modern sector of the economy, however apparently Moldova is not able to compete successfully in these modern, technologically advanced areas of economic activity. This is an unfortunate trend from the point of view of Moldova's developmental aspirations, but probably an unavoidable effect of the increased competition associated with opening to trade and globalization. International experience proves that as a rule efforts to support the declining industries and forestall the destruction of non-viable jobs are costly but ultimately futile. Instead, effort should be concentrated on fostering job creation through removing constraints to firm growth in areas where Moldova has comparative advantage.

By their very nature, expanding industries differ from the declining ones. Most of the new jobs in Moldova are being created in the service sector, while jobs that are being destroyed are largely in the manufacturing and construction sectors. This reflects a natural process of restructuring associated with the decreasing share of manufacturing and the increasing share of services in a modern economy. This process has already taken place in mature market economies and is currently under way in transition economies.

Despite some positive developments, the service sector as a whole does not create enough jobs in Moldova. It is not able to provide employment to workers who lost their manufacturing jobs, let alone workers who are underemployed in agriculture. In 2001 the manufacturing sector reduced the total number of jobs in the economy by about 1.5 percent. At the same time, the service sector created no new jobs on the net basis, thus 
not providing employment opportunities for the workers displaced in manufacturing. To absorb workers released in the manufacturing sector, the annual gross job creation rate in the service sector should be about 14 percent, that is 50 percent higher than the current one. Put differently, the service sector should grow at a yearly rate close to 5 percent to make up for job losses in manufacturing (given the current rate of job destruction). Given that the service sector does not expand in Moldova, it is effectively holding back the reallocation of labor necessary for industrial restructuring.

The actual picture is more bleak than that implied by the recent snapshot data. During the five year period of 1997-2001 the number of service jobs has not only fallen, but fallen even more sharply than the number of manufacturing jobs. This means that the share of services in employment decreased rather than increased (by about 6 percentage points). ${ }^{22}$ Combined with the substantial increase in the share of agriculture (by about 8 percentage points) this implies a reverse development of the Moldavian economy, that is a movement toward a backward employment structure.

This inverse trend is not sustainable. The service sector needs to grow in order to support industrial restructuring necessary for economic growth and poverty reduction. An obvious question is thus why the service sector, unlike in successful transition economies, does not expand in Moldova. Evidence again points to the unfavorable business environment, particularly to regulations of business openings. A study for OECD countries by Lopez-Garcia (2003) found that "[...] countries with higher start-up costs have significantly lower service employment and higher unemployment” [p. 38]. This is because "service employment occurs on average in smaller and more decentralized establishments than manufacturing and successful new job creation in services requires the setting up of new companies" [p. 8]. This leads to a more general conclusion that "Countries where starting a business is cumbersome have failed to accommodate the employment shift from manufacturing and agriculture into services, at the cost of higher unemployment" [p. 8].

Thus, empirical evidence indicates that there is a strong link between the costs of starting a business and the growth of the service sector and the level of unemployment.

$22 \quad$ Based on the Labor Force Survey data presented in DSS (2002). 
Accordingly, the underdeveloped and stagnant service sector in Moldova is yet another symptom of the poor business environment. The weak performance of the service sector in Moldova is especially telling given that in most transition economies of CEE the service sector has substantially expanded, at least in terms of its share in employment and value added. This has even happened in countries which like Moldova have experienced a protracted economic crisis, as for example Bulgaria. Against this background, the shrinking service sector should be of particular policy concern in Moldova.

Analysis of correlations between different elements of job turnover across industries offers additional insights as to the nature of industrial restructuring in Moldova. There are three relations worth noticing. First, there is a lack of correlation between job creation and job destruction rates $(\mathrm{r}=0.14)$. This means that job creation is does not follow job destruction, that these two processes are decoupled. Put differently, the economy is not divided into the high- and the low-job turnover segments. Instead, industries differ as regards the relationship between job creation and job destruction. For example, in some industries high job destruction coincided with high job creation, in others with low job creation.

Second, three is the strong correlation between job reallocation and job creation $(\mathrm{r}=0.91)$. This means that industries which create more jobs are undergoing faster restructuring. By contrasts, there is no correlation between job reallocation and job destruction. This is additional evidence that low job creation, not low job destruction, is a factor limiting industrial restructuring.

Third, three is a strong correlation between employment growth and job destruction $(\mathrm{r}=-70)$ and somewhat weaker correlation between employment growth and job creation $(\mathrm{r}=0.61)$. This means that industry employment growth is determined more by job destruction than job creation. This is in contrast with Lithuania, where industry employment growth is largely determined by the rate of job creation, and tends to be independent of the rate of job destruction. In Lithuania one witnesses "creative destruction" while in Moldova it is the "destruction without creation" that prevails.

To conclude, recently some positive signs have emerged as regards industrial restructuring in Moldova. There are a few expanding industries, mainly in the services 
sector, which drive the growth of the economy. However, overall the restructuring process has been slow and there are signs of a "reverse development", that is a move toward an obsolete employment structure. First, the agriculture's employment share has gone up, indicating that the agricultural sector has acted as the "shock absorber" of the economic transition. That by itself is not necessarily a bad thing, and similar process has occurred in other transition economies, such as Poland and Romania.

Second, employment in the services sector has fallen faster than in other sectors, lowering the services' share in employment. This is a more worrisome trend, which runs counter to developments in other transition economies, where the service sector has expanded during the transition and has been the main provider of new jobs. The employment structure biased toward agriculture and manufacturing is unsustainable in the longer run, implying that industrial restructuring - accompanied by the reallocation of labor and structural unemployment - is still ahead of Moldova. In order to facilitate this process and minimize its social costs, existing barriers to firm creation and growth need to be removed. So far, Moldova has experienced substantial job destruction without much restructuring. The challenge now is to turn the process into "creative destruction" whereby the destruction of old jobs in the declining segments of the economy is offset by the creation of new jobs in the expanding segments.

\section{Region}

The analysis of job turnover by region sheds light on the regional labor market conditions, helps to identify expanding and declining regions, and finally shows the extent of regional restructuring.

The regional picture of job turnover in Moldova is dim. The regional distribution of job opportunities is very uneven. The only region where employment is growing is the capital region. In all other regions job creation falls short of job destruction (Figure 4). In many regions job creation is negligible, while job destruction is substantial, implying large employment losses. In fact, most of the regions in Moldova exhibit such a negative pattern of low job creation coupled with high job destruction.

This low job creation and associated employment decline in all regions except the capital one implies that there is little reallocation of jobs across regions. Regional job 
flows are limited as there are no expanding regions which can absorb labor released from the contracting regions. Instead, the only promising destination for labor migration is the capital region (setting aside migration abroad), which can aggravate rather than ameliorate regional imbalances (see below).

\section{Figure 4 Job Creation by Region, 2001}

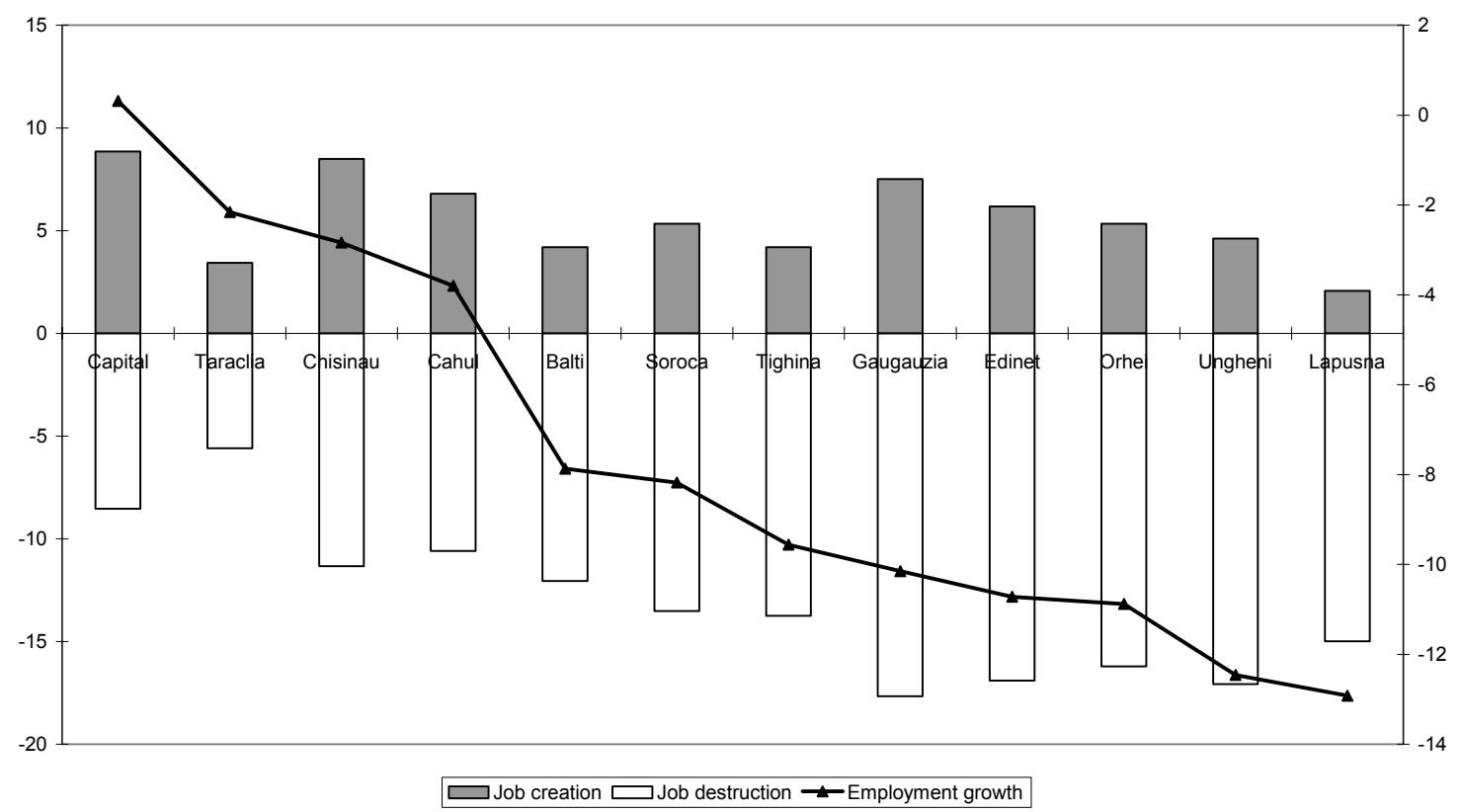

Note: the rate of employment growth is shown on the right-hand axis.

Source: Annual Survey of Enterprises, 2000 and 2001; author's calculations.

Cross-regional correlations of the components of job turnover further support the negative assessment of regional developments in Moldova. Three results are worth noting: ${ }^{23}$

- Across regions, job creation is delinked from job destruction, that is the destruction of old jobs is not followed by the creation of new jobs;

- Low regional job creation rates, falling uniformly short of job destruction rates, leave little room for regional restructuring;

23 The results of cross-regional correlations are strikingly similar to that of cross-industry correlations. 
- Regional employment growth is determined by job destruction rates, and much less influenced by job creation rates, meaning that high job destruction is a defining characteristic of regional labor markets.

The strong concentration of employment opportunities in just one, small capital region is a negative phenomenon. It may lead to the so called "backwash effect", whereby labor, especially skilled labor, and capital move from the peripheral, depressed regions to the buoyant center (the capital region). This movement depletes the disadvantaged regions' essential resources, thus further reducing their growth potential and aggravating their labor market problems, in effect reinforcing regional disparities. As a result of this "circular and cumulative causation" peripheral regions may get trapped in a vicious circle of poverty. ${ }^{24}$

On the other hand, there are benefits of the emergence of a growth center. The backwash effect may be countered by the "trickle-down" or "spread" effects - the favorable effects on the backward regions of growth in the expanding region. These effects may include an increase in the demand for products from less developed regions as a result of income growth which originated in the expanding region, and consequently job creation and employment growth in the economy at large. However in the short- to medium-term the backwash effect is likely to outweigh the trickle down effect. If so, the emerging pattern of strong regional concentration of job opportunities in Moldova carries a risk of becoming self-reinforcing, and thus undermining future development chances of backward regions.

To conclude, job opportunities are relatively buoyant and employment has increased only in the capital region. In all other regions employment has shrunk. This strong concentration of job opportunities in the capital region carries significant risks. It implies that job flows across regions are limited, which reinforces the uneven distribution of job opportunities. Furthermore, this divide into a "center" and a "periphery" is likely to be associated with a "backwash effect" whereby skilled labor migrates from the depressed peripheral regions to the expanding capital region, further weakening the already poor development prospects of the backward regions. The only way to counter 
this risk is to create a favorable investment climate and to improve infrastructure in the backward regions, so that they become more attractive for investment.

\section{II.5 Determinants of employment growth}

There are a number of factors that affect firms' employment decisions. These include access to credit, export orientation, ownership structure, capital density, investment, labor costs, etc. In a number of countries these factor have proven to be good predictors of changes in employment at a firm level (Rutkowski, 2003a, 2003b). We tried to determine the relationships between these factors and employment changes for Moldova, but it turned out that there are no clear patterns. For example, there is no discernible relationships between changes in employment and export orientation or investment. Moldovan firms which have access to foreign markets do not seem to increase employment more than firms which do not. Nor firms which invest more seem to see faster employment growth. This apparent lack of relationship between employment and its presumed determinants may reflect a high degree of "noise" in the data. However, it may also reflect the fact that the product and labor markets have not achieved a new equilibrium yet, and thus firms behave in a way that is not consistent with what the theory predicts.

The only relationship that comes out very clearly is that between employment changes and firm productivity (Figure 5). Firms' job creation performance visibly improves with the level of labor productivity. Firms which are least productive reduce employment the most. At the same time, the most productive firms expand employment. To illustrate, the least productive firms (bottom quintile of labor productivity) reduced employment on average by 16 workers. In contrast, the most productive firms (top quintile) increased employment on average by 7 workers in 2001. 
Figure 5 Employment growth and productivity, 2001

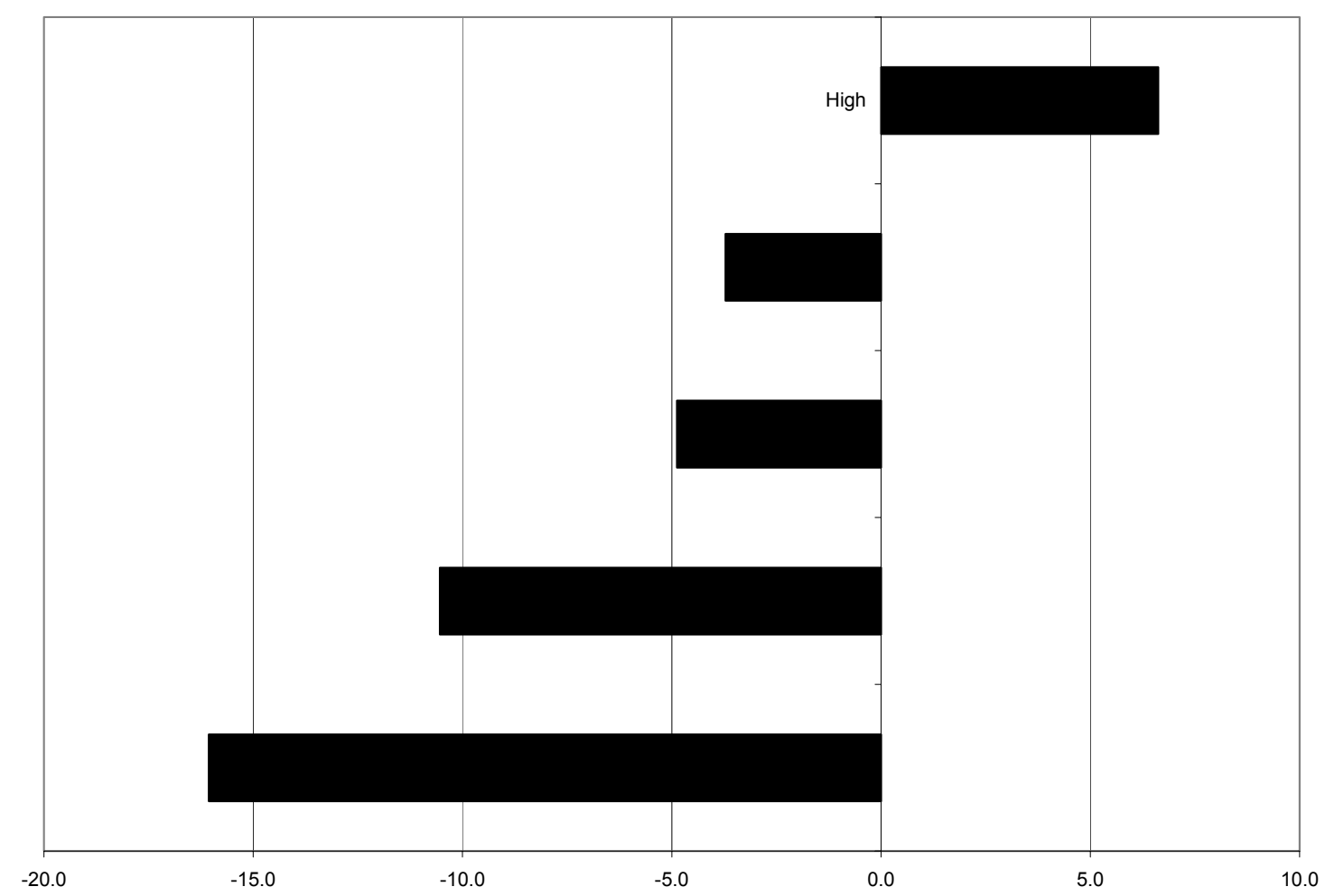

Source: Annual Survey of Enterprises, 2001; author's calculations.

The positive association between productivity and employment growth is an important finding. Often an increase in productivity coincides with a reduction in employment and thus in popular perception there is a trade-off between productivity and employment. That is, higher productivity is believed to come at a price of lower employment. In contrast to this belief, the evidence shows that higher labor productivity is good for job creation. Only the most productive firms can afford to expand and hire more labor. Thus improvements in productivity of Moldovan firms are crucial for faster job creation.

Firms which are the most productive tend to be privately owned. Figure 6 illustrates this point. The productivity differential between private firms and publicly owned firms is quite striking. This indicates that the restructuring of publicly owned 
firms has just started in Moldova and is far from being completed. ${ }^{25}$ This may have negative implications for employment: all else being equal, productivity improvements in inefficient, overstaffed public firms will require employment reductions.

Productive firms also tend to be small (Figure 6). Moreover, the variation of labor productivity by firm size is very high, with a huge differential between large and small firms. This again points to delayed restructuring. Large (as a rule publicly owned or privatized) firm will have to downsize in order to bridge the productivity gap and become competitive.

25 The successful restructuring of public firms entails closing the productivity gap between public and private firms. 
Figure 6 Labor Productivity by Firm Ownership and Size, 2001

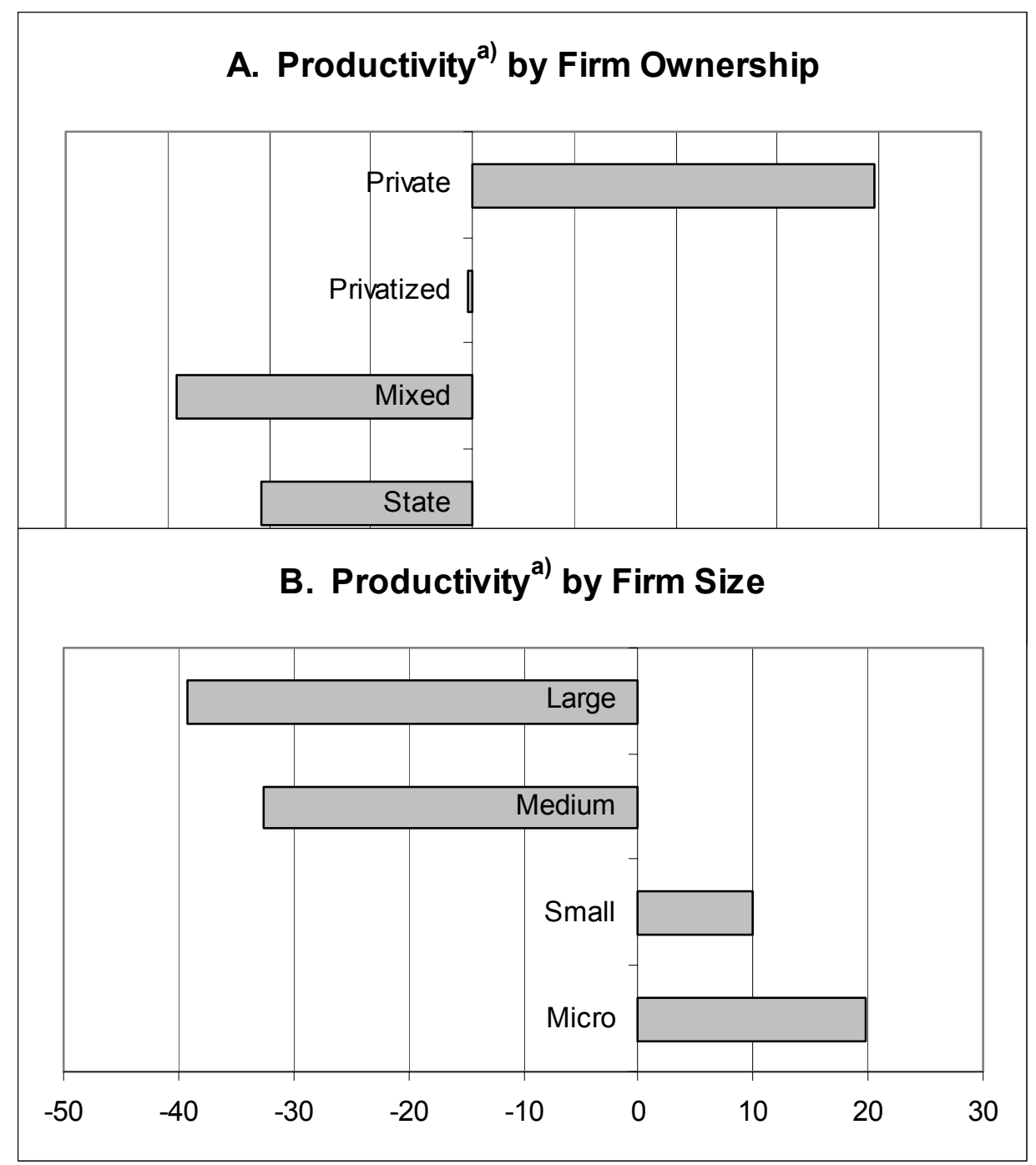

a) Percentage deviation from the mean.

Source: Annual Survey of Enterprises, 2001; author's calculations.

To sum up, there is a positive relationship in Moldova between labor productivity and employment growth. High productivity firms create jobs, while low-productivity firms eliminate jobs. High productivity firms tend to be privately owned and small. Publicly owned and privatized firms are lagging behind and will need to shed labor in order to improve their competitiveness. To counteract this negative employment effect of 
enterprise restructuring, it is necessary to foster the formation and growth of small private firms.

\section{BARRIERS TO JOB CREATION}

The analysis in the preceding section has shown that firm entry is limited and job creation is slow in Moldova. Although firm exit is also limited, job destruction in existing firms is pretty high. The latter finding suggests that employment protection regulations are not so stringent as to discourage the elimination of unproductive jobs, and thus play a secondary role in explaining labor market outcomes. Of primary importance is the cause of low firm and job creation. A main suspect is the unfavorable business environment and high costs of doing business. The aim of this section is to determine if indeed the costs of doing business in Moldova are so high as to explain the poor job creation record. We start by examining regulations on firm entry and on labor, as most directly related to firm and job creation. Next we try to identify problem areas - those regulations which "tax" businesses the most - using employers' assessment, as well as objective indicators of the stringency of business regulations.

\section{Entry regulations}

Costs of starting a business are relatively high in Moldova but not out of line compared to those in other transition economies, or some highly regulated EU economies. However, they are substantially higher then in less regulated, low unemployment EU economies, such as Denmark, Ireland or U.K. (Table 5). Specifically, to open a firm, a prospective Moldavian businessman needs to complete 11 procedures (obtaining necessary permits and licenses, etc.), which takes some 40 days. He/she also needs to incur costs, which account for about 30 percent of income per capita. ${ }^{26}$ Finally, he/she needs to have a starting capital of at least 100 percent of income per capita. All this is not excessive by international standards, however in high job creation economies these costs are substantially lower. For example, in low unemployment EU countries the number of procedures does not exceed 5, the time necessary to complete them is less than

26 This includes only formal payments. They may substantially under-represent actual costs, as corruption is widespread in Moldova. 
half a month, and associated monetary costs are negligible. But even some transition economies - which in general tend to be on the high end in terms of the costs of doing business - do considerably better than Moldova. For example, in Latvia opening a business is much less costly: there is fewer procedures, completing them takes less time, and associated expenses are lower.

Table 5 Entry regulations indicators in selected transition and EU economies, 2002

\begin{tabular}{lrrrr}
\hline \multicolumn{1}{c}{ Country } & $\begin{array}{c}\text { Number of } \\
\text { Procedures }\end{array}$ & $\begin{array}{c}\text { Duration } \\
\text { (days) }\end{array}$ & $\begin{array}{c}\text { Cost (\% of } \\
\text { GNI per } \\
\text { capita) }\end{array}$ & $\begin{array}{c}\text { Min. Capital } \\
\text { (\% of GNI } \\
\text { per capita) }\end{array}$ \\
\hline Transition economies & 10 & 30 & 9 & 150 \\
Bulgaria & 10 & 89 & 5 & 50 \\
Czech R. & 5 & 65 & 65 & 222 \\
Hungary & 7 & 11 & 17 & 110 \\
Latvia & 11 & 62 & 5 & 85 \\
Lithuania & 11 & 41 & 31 & 106 \\
Moldova & 11 & 58 & 23 & 23 \\
Poland & 9 & 46 & 36 & 415 \\
Romania & & & & \\
EU economies & & & & \\
Low unemployment & 3 & 3 & 0 & 47 \\
Denmark & 3 & 16 & 10 & 0 \\
Ireland & 5 & 4 & 1 & 0 \\
United Kingdom & & & & \\
High unemployment & 10 & 53 & 3 & 29 \\
France & 9 & 45 & 6 & 93 \\
Germany & 11 & 100 & 16 & 18 \\
Spain & & & & \\
\hline
\end{tabular}

Source: The World Bank Doing Business database (http://rru.worldbank.org/DoingBusiness)

The costs of opening a business in Moldova rise substantially if one accounts for bribes which often need to be paid to obtain necessary permits and licenses. One firm in five reports that it paid bribes in order to register, and the average payment was USD 120, which is a non-negligible amount in the Moldavian context. It is impossible to know how many potential entrepreneurs get discouraged by corruption and thus abandoned the idea of starting a business, or moved to the informal sector.

All in all, there is room for lowering the costs of starting a business in Moldova. First, registration procedures can be streamlined, and the associated payments and capital requirements can be lowered. For example, those with entrepreneurial talent who are poor may not be able to afford registration costs, which are non-negligible. This may 
effectively push some small entrepreneurs into the informal sector. Second, the costs resulting from corruption can be lowered by reducing the number of permits and licenses, and by limiting the discretionary power of bureaucrats. This can be done by specifying clear rules and transparent criteria which govern granting a permit or a license (Djankov et al., 2001).

\section{Employment regulations}

Employment protection legislation is very stringent in Moldova. It is stringent even compared to other post-socialist countries, which all inherited labor laws granting workers generous rights. It is also more strict than in most EU countries, including those - such as Germany and France - where labor markets are heavily regulated (Table 6). Specifically, flexible forms of employment (e.g. fixed-term contracts) are restricted, working conditions are heavily regulated, and dismissals are difficult (e.g. the law requires trade union approval of dismissals).

Table 6 Employment regulations indicators in selected transition and EU economies, 2002

\begin{tabular}{lcccc}
\hline \multicolumn{1}{c}{ Country } & $\begin{array}{c}\text { Alternative } \\
\text { Employment } \\
\text { Contracts }\end{array}$ & $\begin{array}{c}\text { Conditions of } \\
\text { Employment }\end{array}$ & $\begin{array}{c}\text { Job } \\
\text { Security }\end{array}$ & $\begin{array}{c}\text { Employment } \\
\text { Laws Index }\end{array}$ \\
\hline Transition economies & & & & \\
Bulgaria & 0.55 & 0.87 & 0.31 & 1.73 \\
Czech Republic & 0.33 & 0.63 & 0.35 & 1.31 \\
Hungary & 0.62 & 0.90 & 0.22 & 1.73 \\
Latvia & 0.56 & 0.81 & 0.41 & 1.77 \\
Lithuania & 0.62 & 0.86 & 0.34 & 1.82 \\
Moldova & 0.78 & 0.73 & 0.56 & 2.07 \\
Poland & 0.56 & 0.91 & 0.46 & 1.92 \\
Romania & 0.65 & 0.82 & 0.30 & 1.77 \\
EU economies & & & & \\
Low unemployment & & & & \\
Denmark & 0.56 & 0.22 & 0.12 & 0.90 \\
Ireland & 0.56 & 0.43 & 0.12 & 1.11 \\
United Kingdom & 0.56 & 0.31 & 0.08 & 0.94 \\
High unemployment & & & & \\
France & 0.74 & 0.54 & 0.31 & 1.59 \\
Germany & 0.72 & 0.40 & 0.50 & 1.62 \\
Spain & 0.83 & 0.86 & 0.50 & 2.19 \\
\hline
\end{tabular}

Note: higher values of the index indicate more restrictive regulations.

Source: The World Bank Doing Business database (http://rru.worldbank.org/DoingBusiness) 
In theory, strict employment protection legislation is expected to discourage hiring and rises the costs of employment adjustment. If employers find it difficult and costly to reduce employment during the downturn, they are reluctant to hire labor and increase employment during the upturn. This is a rational behavior aimed at minimizing expected labor costs.

It is tempting to attribute the low job creation rate in Moldova to strict employment protection. However, in order to establish such a link one first needs to determine if relevant regulations are observed and enforced. Available evidence suggests that this is not the case in Moldova. First, as shown earlier, the job destruction rate is in Moldova is relatively high, implying that costs of eliminating redundant jobs are not prohibitive.

Second, overstaffing is not a major problem in Moldova. Actually, it seems to be less of a problem than in some transition economies with apparently more flexible labor markets. For example, only 5 percent of Moldavian firms would reduce their employment 20 percent or more, were the regulations on dismissal absent, compared with 6 percent of firms in Hungary and 12 percent in the Czech Republic, i.e. countries where the employment protection legislation is relatively liberal and significantly less strict than in Moldova. ${ }^{27}$

Finally, and perhaps most importantly, employers themselves do not regard labor regulations as an important problem negatively affecting their business. Or at least, problems associated with labor regulations are thwarted by others, such as those relating to custom procedures, permits, certificates, licenses and inspections. According to the results of a focus group (comprising managers from small and medium sized enterprises), labor regulations are perceived as the least important problem facing employers (score of 1 on a scale form 0 to 10$){ }^{28}$

All this means that, although stringent in theory, in practice labor regulations have little bite as they are mostly ignored and not enforced. In other words, the low job

\footnotetext{
27 These results come from of the second round of the Business Environment and Enterprise Performance Survey (BEEPS II) conducted in 2002 by the World Bank and the EBRD. Survey results are available at: http://info.worldbank.org/governance/beeps2002.

$28 \quad$ MAEWS Focus Group, Chisinau, Moldova, December, 2002.
} 
creation rate in Moldova is unlikely to be caused by the strict employment protection legislation. This leads us to continue the search for the elements of the business environment which could account for low job creation.

\section{What renders the business environment unfriendly in Moldova?}

When Moldavian employers are asked this question they point to high (monetary and procedural) costs of obtaining permits, certificates and licenses, to complicated custom procedures and to high costs associated with various inspections. These impediments are perceived as severe: on a scale from 0 to 10 they get scores in the range of 7 to 10 . That is, they represent a substantial constraint on business activity. ${ }^{29}$

The perception that doing business in Moldova is costly and difficult is well grounded in reality. The results of the Regulatory Cost Assessment Survey for 2000-2002 clearly show that business regulations in Moldova impose a huge burden on management time and firm resources (ProEra, 2003). They dramatically reduce returns to economic activity by both raising costs and lowering benefits. Low expected returns discourage new firm formation, and high costs associated with regulations limit the scale of production. This translates into less jobs, lower employment and ultimately higher poverty. The welfare costs of the unfriendly business environment are substantial.

The number of required permits, certificates and licenses is huge, they need to be obtained frequently, it takes a long time to obtain them and associated monetary payments - formal and informal - are high. For example, it takes almost half a year to obtain a construction permit at a cost exceeding USD 1,000. Permits are also required to renovate premises, change their profile and to utilize them. Of course, there are many other permits, such as export permits, import permits, equipment permits, hygienic permits, etc. Obtaining certificates for goods and services is an equally costly process. On average a business needs to go through certification procedure for goods 18 times per year, and each certification takes on average 11 days and costs USD 152. A separate procedures exist for the certification of production lines (ProEra, 2003).

29 MAEWS Focus Group, Chisinau, Moldova, December, 2002. 
Extremely high costs are associated with frequent inspections and audits. At least 15 state agencies have the authority to control economic units. An average Moldovan firm paid host to 20 inspections in 2002. Inspectors spent on average 48 days per year per firm in 2001. Although this may seem a lot of time, the corresponding figure for the previous year was almost twice as high (90 days), so there has been some improvement in this area. Inspections are extremely costly: an average firm paid USD 1280 in fines and USD 516 in bribes and "voluntary contributions"; in additions the value of confiscations was USD 300 per firm. These costs are huge not only in absolute terms, but also in comparison to those in other countries in the regions. For example, the inspection costs in Bulgaria, Belarus and Ukraine were significantly lower than in Moldavia. ${ }^{30}$ This is very telling, because none of these countries represents a particularly good standard of the business environment. But Moldova fares poorly even against such a modest benchmark.

One could continue to list further examples of overregulation and associated costs, however no more examples seem necessary to arrive at the conclusion that the sate imposes an extremely high tax - in the broad sense of the word - on business activity. There is no single element that is responsible for the business environment being unfriendly in Moldova. It is the whole regulatory system, bureaucratic discretion, and the underlying philosophy of taxing businesses that are the root cause of depressed economic activity in Moldova. Therefore a fundamental overhaul of the business regulations system is necessary to improve the investment climate. The overarching objective of such an overhauls should be to deregulate business activity and to lessen the scope for bureaucratic discretion and arbitrary decisions. The monetary costs associated with regulations need to be lowered with the aim of maximizing long-term benefits instead of short-term gains. Ultimately, a radical improvement in the business environment is the only way to foster job creation and to improve employment opportunities.

The government is aware of the excessive regulation and control over business activity. For example, recently the government took measures to coordinate and

30 Comparison is limited to these three countries as they are the only ones where the comparable survey of regulatory costs was conducted. 
consolidate inspection and audit activities. ${ }^{31}$ This is a step in the right direction, which needs to be followed by further ambitious reforms.

To conclude, the costs of doing business in Moldova are extremely high. It is not possible to single out a particular element of the business environment which accounts for these high costs. Rather it is the whole environment which is not business friendly owing to excessive regulations, bureaucratic discretion and associated corruption, and focus on maximizing short term revenues through extraction of money from businesses. Such an environment causes high economic and social inefficiency. By reducing returns to entrepreneurship it inhibits business formation and expansion. It hits small businesses, which find it most costly to comply with regulations, particularly hard. These are exactly the businesses which are few in Moldova, but which are the most productive and create new jobs. Thus, a radical improvement in the business environment (including the reduction in the number of permits, certificates and licenses, as well as in the number and frequency of inspections) is a prerequisite for employment growth and ultimately poverty reduction.

\section{CONCLUSIONS AND POLICY IMPLICATIONS}

The low unemployment rate in Moldova masks a depressed labor market. The employment rate is low, meaning that labor resources are underutilized. In addition, many existing jobs are characterized by low productivity. This relates to jobs in enterprises that struggle to survive, as well as to casual, temporary jobs held by some of the self-employed. In this context, the low unemployment rate is a misleading indicator of labor market conditions. A large number of discouraged workers, considerable external migration, and sizeable informal sector employment imply a slack labor market.

The rate of job creation in the formal sector is relatively low, while the rate of job destruction is high. The gap between job creation and job destruction implies that formal sector employment is shrinking. It also implies that industrial restructuring is limited, as too few jobs are being created in the "new" sector to absorb labor released in the "old", declining sector. Thus there is high job destruction without much restructuring. In particular, there are some symptoms of "reverse development" as services as a share of

$31 \quad$ Decrees No. 168 and 395 issued in early 2003. 
total employment have declined while industry and especially agriculture have increased. This is in contrast to successful transition economies, where the service sector has been expanding both in absolute and relative terms.

The high rate of job destruction is typical of the restructuring in transition economies and reflects the elimination of low-productivity, non-viable jobs in the declining, inefficient sectors of the economy. As such, this is not a negative process. The source of negative labor market dynamics in Moldova is not high job destruction, but low job creation. Prima facie, slow job creation is caused by the low rate of firm births and by the small fraction of expanding firms. It is only the de novo private and small firms that are competitive and create jobs on a net basis. However, the share of these firms in employment is low, substantially lower than in successful transition economies. In this sense, the industrial structure in Moldova is not supportive of job creation.

The low rate of creation of new firms, the relatively low number of expanding small private firms, and lack of job opportunities in the service sector all point to the unfavorable business environment. Indeed, Moldovan firms are strangled by overregulation, bureaucratic harassment and extortion. The costs of doing business in Moldova are extremely high even by regional standards, which discourages firm formation and expansion. The result is slow job creation, lack of employment opportunities, and ultimately poverty.

To overcome these negative trends, the rate of job creation needs to be substantially increased (attempts to forestall the destruction of non-viable jobs are usually counterproductive). Given that most firms are downsizing, the way to increase the number of available jobs is to increase firm density. This requires faster firm creation, and the only way to achieve this is to improve the investment climate. Improving the investment climate in Moldova will require radical reforms, including deregulating business activities, lessening the discretionary power of the bureaucracy, and instead introducing clear rules and transparent criteria governing administrative decisions affecting businesses. Furthermore, not only the number of various permits needs to be substantially reduced, but also the associated costs. In short, the current extremely high 
level of taxation of businesses needs to be substantially lowered. This should be the top priority of any policy to foster job creation.

As a further priority, the Labor Code needs to be revised so as to make the labor market more flexible and to encourage hiring. Currently, rigidities imposed by the Labor Code do not seem to be binding, as the regulations are neither observed nor enforced. And most importantly, they are thwarted by constraints springing from stringent regulations on business activates. However, improving labor market flexibility is necessary to create a solid foundation for employment growth in the future.

A final note refers to the so-called active labor market programs (ALMPS). There are high expectations in Moldova as regards their role in improving the employment chances of the jobless. However, the potential of ALMPs is limited, especially when the labor market is depressed. Although ALMPs can help some unemployed to find a job, they hardly create new jobs and thus cannot be substituted for measures aimed at improving the business environment and job creation. ALMPs are meant mainly to help disadvantaged worker groups and can be developed in Moldova on a limited scale to advance this objective. Efforts to increase employment should be concentrated on improving the business environment. 


\section{REFERENCES}

Andrews, Emily (2003), Evaluation of the Labor Market in Moldova. Background paper for the Moldova Poverty Assessment study, World Bank, processed.

Blanchard, Oliver and Justin Wolfers (2000), "The Role of Shocks and Institutions in the Rise of European Unemployment: The Aggregate Evidence", Economic Journal, 110: C1-C33.

Boeri, Tito and Joaquim Olivera Martins (2000), Varieties, Jobs and EU Enlargement, William Davidson Institute, Working Paper No. 301.

Boeri, Tito, Giuseppe Nicoletti and Stefano Scarpetta (2000), "Regulation and Labour Market Performance", Centre for Economic Policy Research, Discussion Paper No. 2420 .

Djankov, Simeon, Rafael La Porta, Florencio Lopez-de-Silanes, and Andrei Shleifer (2000), The Regulation of Entry, Harvard Institute of Economic Research Discussion Paper No 1904.

DSS (2002), Labour Market in the Republic of Moldova, Chisinau.

Eurostat (2000), New Enterprises in Central European Countries in 1998, Luxembourg.

Garibaldi, Pietro and Paolo Mauro (1999), "Deconstructing Job Creation”, IMF Working Paper, WP/99/109.

Haltiwanger, John, Stefano Scarpetta, and Milan Vodopivec (2003), "How Institutions Affect Labor Market Outcomes: Evidence From Transition Countries”, World Bank, processed.

Heckman James J. and Carmen Pages (2000), The Cost of Job Security Regulation: Evidence from Latin American Labor Markets, NBER Working Paper No. 7773

Hirschman, Albert (1958), The Strategy of Economic Development, New Haven, Conn.: Yale University Press.

Krueger, Alan B. and Jorn-Steffen Pischke (1997), "Observations and Conjectures on the U.S. Employment Miracle”, Princeton University, Industrial Relations Section, Working Paper No. 390.

Lindauer, David L. (1999), "Labor and Poverty in the Republic of Moldova", in Moldova: Poverty Assessment Technical Papers, The World Bank.

Lopez-Garcia, Paloma (2003), "Labour Market Performance and Start-up Costs: OECD Evidence", CESIFO Working Paper No. 849.

Myrdal, Gunnar (1957), Economic Theory and Underdeveloped Regions, London: Duckworth.

Nickell, Stephen (1997), "Unemployment and Labor Market Rigidities: Europe versus North America”, Journal of Economic Perspectives, Vol. 11, Issue 3, 55-74

ProEra Group (2003), Report on the Regulatory Costs Assessment Survey of the Republic of Moldova during the 2000-2002 period, processed. 
Rutkowski , Jan (2001), "Job Creation and Job Destruction in Poland (1993-1999)," Background Paper prepared for Poland's Labor Market: The Challenge of Job Creation, World Bank, Washington, D.C., mimeo.

Rutkowski, Jan (2003a), "Rapid Labor Reallocation with a Stagnant Unemployment Pool: The Puzzle of the Labor Market in Lithuania", Policy Research Working Paper No. 2946, World Bank, Washington, DC.

Rutkowski, Jan (2003b), Why is Unemployment so High in Bulgaria?, Policy Research Working Paper No. 3017, World Bank, Washington, DC.

Rutkowski, Jan (2003c), "Does Strict Employment Protection Discourage Job Creation? Evidence from Croatia", Background paper prepared for the Croatia Country Economic Memorandum, World Bank, Washington, DC, mimeo.

Scarpetta, Stefano, Philip Hemmings, Thierry Tressel and Jaejoon Woo (2002), "The Role of Policy and Institutions for Productivity and Firm Dynamics: Evidence from Micro and Industry Data", OECD Working Paper No. 329.

World Bank (2002), Transition: the first Ten Years. Analysis and Lessons from Eastern Europe and the Former Soviet Union, Washington, DC. 


\section{ANNEX 1 \\ DERIVATION OF THE FORMULA FOR THE CHANGE IN THE EMPLOYMENT RATE}

Employment (the number of jobs), $L$, is a product of the total number of firms, $F$, and the average firm employment size, $M$ :

$$
L=F \cdot M
$$

The rate of employment growth, $e$, is thus a sum of the growth rate of the number of firms, $f$, and the proportionate change in the average firm size, $m:{ }^{32}$

$$
l=f+m
$$

The growth in the number of firms, $f$, is a difference between the firm creation rate, $f^{\mathrm{c}}$, and firm destruction rate, $f^{\mathrm{d}}$, that is:

$$
f=f^{c}-f^{d}
$$

where: $f^{c}=F^{n} / F$ and $f^{d}=F^{x} / F$; subscript $n$ denotes entering firms, and subscripts $x$ denotes exiting firms.

The proportionate change in the average firm size, $m$, can be decomposed into effects due to firm entry, exit, and expansion/contraction in continuing firms. To derive the formula let's start with the following identity, which breaks down total employment down by firm type:

$$
L=F \cdot M=F^{n} \cdot M^{n}+F^{x} \cdot M^{x}+F^{e} \cdot M^{e}+F^{c} \cdot M^{c}
$$

where subscripts have the following meanings: $n$ denotes entering firms, $x$ denotes exiting firms, $e$ denotes expanding firms, and $c$ contracting firms.

Dividing both sides by the total number of firms, $F$, we obtain:

$$
M=s^{n} \cdot M^{n}+s^{x} \cdot M^{x}+s^{e} \cdot M^{e}+s^{c \cdot} M^{c}
$$

where $s$ stands for a share, i.e. $s^{n}=F^{n} / F$, etc. ${ }^{33}$ (Note that $s^{\mathrm{n}}=f^{\mathrm{e}}$ and $s^{\mathrm{x}}=f^{\mathrm{d}}$ ).

It is straightforward to show that:

$$
m=s^{n} \cdot m^{n}+s^{x} \cdot m^{x}+s^{e} \cdot m^{e}+s^{c} m^{c}
$$

32 The formula has an approximate character as it omits second order multiplicative terms.

${ }^{33}$ The initial number of firms $\mathrm{F}$ is a sum of continuing firms and exiting firms. 
Where $m=\frac{d M / d t}{M}$, i.e. $m$ is a proportionate change (the rate of growth), and subscripts have their earlier meanings.

Note that:

$m^{n}=\frac{d M^{n} / d t}{M}=\frac{M^{n}}{M}=r^{n}$

Where $r^{\mathrm{n}}$ is the relative size of entering firms.

Similarly,

$$
m^{x}=\frac{-M^{x}}{M}=-r^{x}
$$

Where $r^{\mathrm{x}}$ is the relative size of exiting firms.

Note further that:

$$
m^{e}=\frac{d M^{e} / d t}{M}=\frac{M^{e}}{M} \cdot \frac{d M^{e} / d t}{M^{e}}=r^{e} \cdot J C^{e}
$$

That is the proportionate change in the average size of expanding firms $m^{\mathrm{e}}$ is equal to the product of the relative size of expanding firms $r^{\mathrm{e}}$ and the job creation rate in expanding firms, $J C^{\mathrm{e}}$. By similar vein:

$m^{c}=-r^{c} \cdot J D^{c}$

Where $J D^{\mathrm{c}}$ stands for the job destruction rate in contracting firms.

Thus (5) can be rewritten as:

$$
m=s^{n} \cdot r^{n}-s^{x} \cdot r^{x}+s^{e} \cdot r^{e} \cdot J C^{e}-s^{c} \cdot r^{c} \cdot J D^{c}
$$

Combining (3) and (6) we get the formula for the rate of employment (jobs) growth:

$$
l=f^{c}-f^{d}+s^{n} \cdot r^{n}-s^{x} \cdot r^{x}+s^{e} \cdot r^{e} \cdot J C^{e}-s^{c} \cdot r^{c} \cdot J D^{c}
$$

Thus, the rate of employment growth depends on the rates of firm creation and firm destruction, $f^{\mathfrak{c}}$ and $f^{\mathrm{d}}$, on the shares $s$ and the relative sizes $r$ of entering, exiting, expanding and contracting firms, and finally on the rate of job creation in expanding firms, $J C^{\mathrm{e}}$, and the rate of job destruction, $J D^{\mathrm{c}}$, in contracting firms. 


\section{ANNEX 2 \\ DESCRIPTION OF THE ANNUAL SURVEY OF ENTERPRISES}

\section{Sampling frame and the sample}

The sample of firms is drawn from the National Register of Firms (RENIM). The survey covers all registered firms employing at least 20 workers, and uses a random sample of smaller (employing up to 19 workers) firms. A system of weights is used to arrive at estimates relating to the general population. The data set used in the analysis was constructed by matching firm records relating to years 2000 and 2001. The main characteristics of the survey are as follows.

\section{Firm coverage}

The survey covers enterprises which are registered legal persons in the nonfinancial sector (i.e. banks, insurance and other financial institutions are excluded from the survey). Accordingly, enterprises which are natural persons are left out of analysis. The latter are small, often one-person, firms. Enterprises which are legal persons account for 45 percent of all enterprises in Moldova. However, given that they tend to be bigger than enterprises which are natural persons, their employment share is much higher (the exact percentage is not available).

\section{Worker coverage}

All employees within the firm, regardless of their employment status (including part-time workers, temporary workers, workers on unpaid leave, etc.).

\section{Definition of employment}

The survey provides information on both average employment and end-of-year employment. For the purpose of the analysis of job creation the employment variable was constructed as total employment minus the number of workers on unpaid leave, both as of December 31. Thus, the employment measure refers to actual as opposed to nominal employment. This is a relevant distinction in the case of Moldovan economy, where the number of workers sent on forced unpaid leave (who are still counted as firm's employees) is non-negligible.

\section{Data cleaning}

In a few cases matched employment records showed implausibly large increases or decreases in firm employment over a year. Such large employment changes are likely to reflect either enterprise mergers, or splits, or can be spurious, i.e., reflect errors in data entry. Given that such outliers have a large weight and bias the data on job creation and destruction, they were removed from the data set. An observation was treated as an outlier if the employment change was large in both absolute and relative terms. A large absolute change was defined as that exceeding three standard deviations. A large relative change was defined as one exceeding 33\% increase/decrease in the employment level over a year. In addition, firms which were classified as inactive by the Department of Statistics were left out. As a result of applying the cleaning procedure 367 observations were removed from the data set, and the working sample comprises 4519 firms.

Basic statistics referring to the original data set and the cleaned data set (used for analysis) are shown in Table A1 
Table A1 The sample structure by size, ownership and sector, 2000.

\begin{tabular}{lrrrr}
\hline \multirow{2}{*}{ Firm category } & \multicolumn{2}{c}{ Original sample } & \multicolumn{3}{c}{ Cleaned sample } \\
\cline { 2 - 5 } & Frequency Percent & Frequency Percent \\
\hline Total & 4886 & 100 & 4519 & 100 \\
Size (employment) & & & & \\
0 & 13 & 0.26 & 4 & 0.09 \\
1 & 248 & 5.08 & 88 & 1.95 \\
$2-10$ & 1259 & 25.77 & 1110 & 24.56 \\
$11-50$ & 1682 & 34.42 & 1658 & 36.69 \\
$51-100$ & 733 & 15.0 & 730 & 16.15 \\
$101-250$ & 585 & 11.97 & 580 & 12.83 \\
$251-10000$ & 366 & 7.49 & 349 & 7.72 \\
Ownership & & & & \\
State & 581 & 11.89 & 553 & 12.24 \\
Collective & 3479 & 71.2 & 3180 & 70.37 \\
Mixed & 391 & 8.0 & 382 & 8.45 \\
Private & 435 & 8.9 & 404 & 8.94 \\
Sector & & & & \\
Agriculture & 840 & 17.19 & 795 & 17.59 \\
Business & 3497 & 71.57 & 3243 & 71.76 \\
Non-business & 549 & 11.24 & 481 & 10.64 \\
\hline
\end{tabular}

Source: ASA 2000; author's calculations. 